
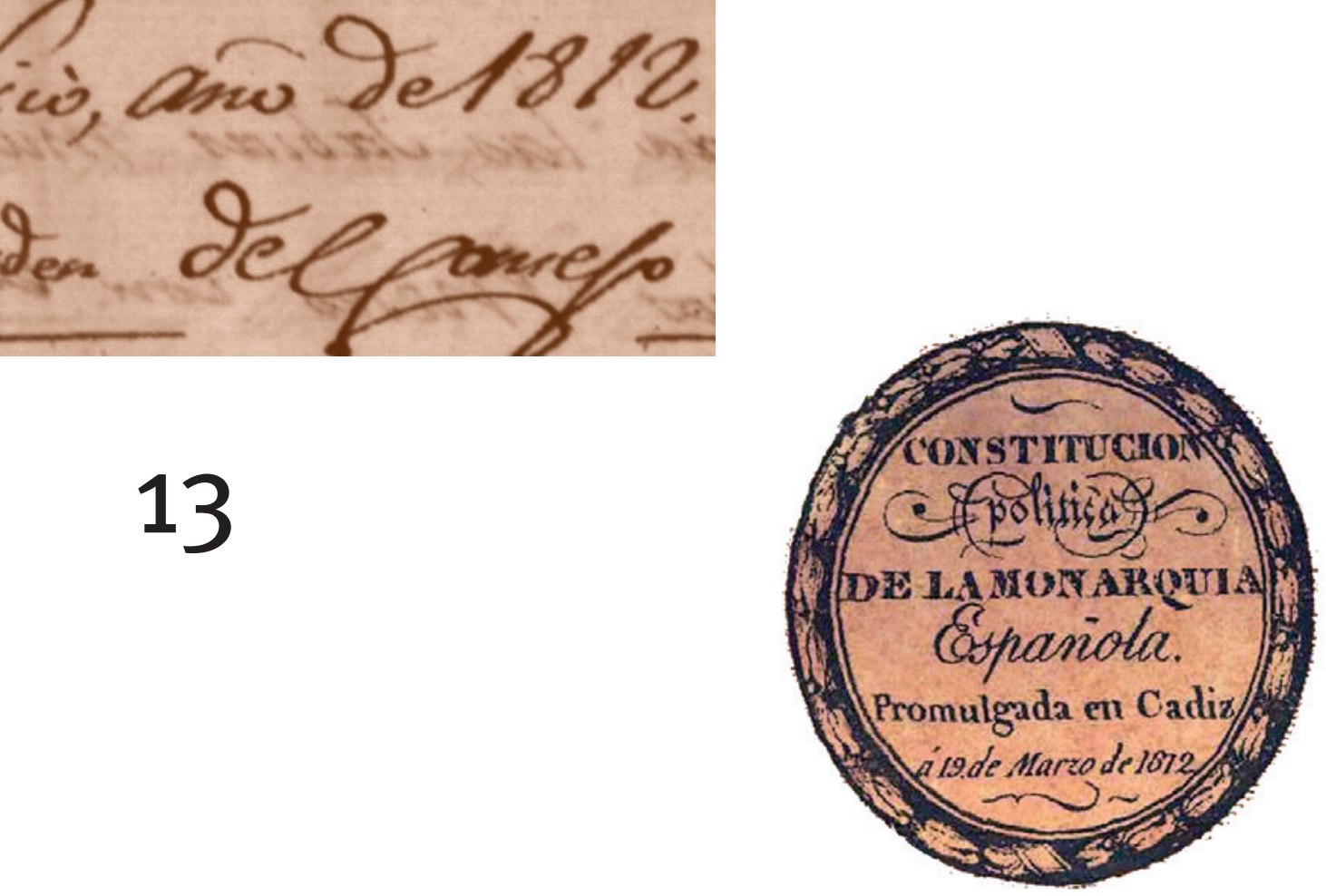

13

romulgada en Cadiz
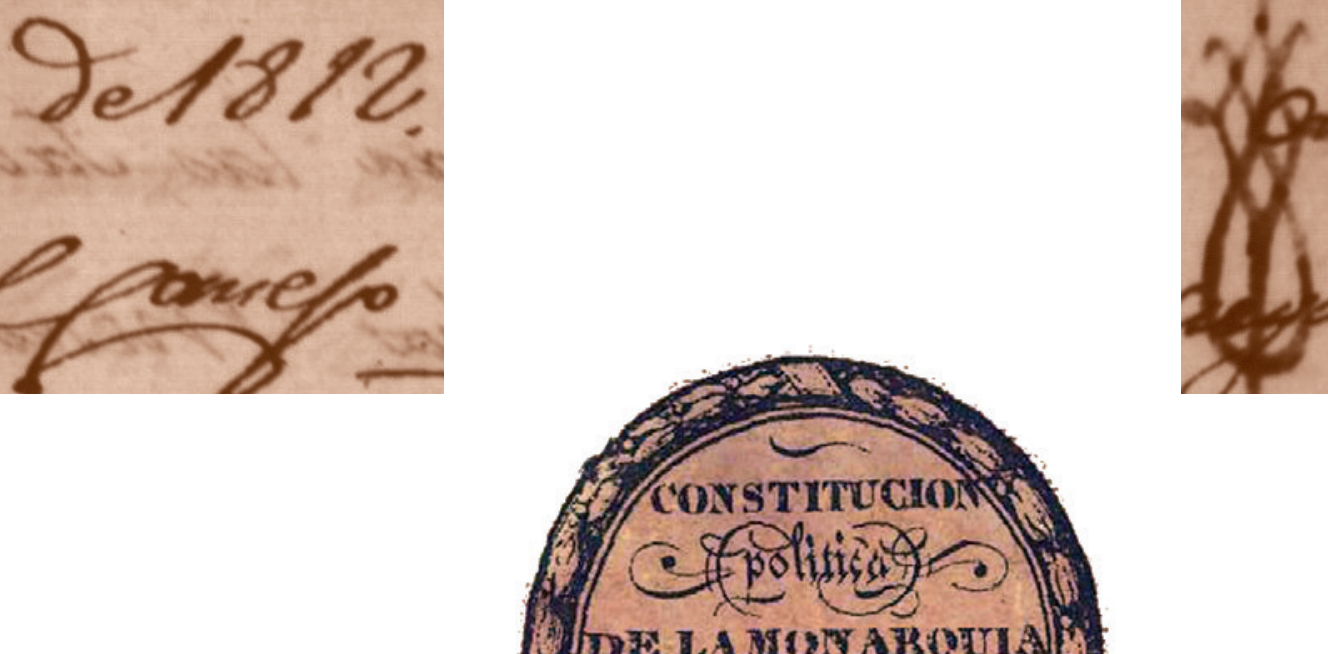



\section{Colección $\mathbf{I m u d}$ \\ n. ${ }^{\text {13 }}$}

\section{LA PROVINCIA DE LA MANCHA Y LA CONSTITUCIÓN DE 1812}





\section{Carlos Chaparro Contreras \\ e Isidro Sánchez Sánchez (eds.)}

\section{LA PROVINCIA DE LA MANCHA Y LA \\ CONSTITUCIÓN DE 1812}

Ediciones de la Universidad

de Castilla-La Mancha

Cuenca, 2021 
LA PROVINCIA de La Mancha y la Constitución de 1812 / editores, Carlos Chaparro Contreras, Isidro Sánchez Sánchez.- Cuenca : Ediciones de la Universidad de Castilla-La Mancha, 2020

341 p. ; 24 cm.- (Almud ; 13)

ISBN 978-84-9044-311-8

1. España - Constitución - 1812 2. Castilla-La Mancha - Historia I. Chaparro Contreras, Carlos, ed. lit. II. Sánchez Sánchez Isidro, ed. lit. III. Universidad de Castilla-La Mancha, ed. IV. Serie

342.4(460)"1812"

946.028

1DSE-ES-G

NHD

(C) de los textos e imágenes: sus autores.

(C) de la edición: Universidad de Castilla-La Mancha.

Edita: Ediciones de la Universidad de Castilla-La Mancha y Centro de Estudios de Castilla-La Mancha.

Colección Almud n. ${ }^{\circ} 13$.

Diseño de la colección:

C.I.D.I. (Universidad de Castilla-La Mancha).

unte Unión de Edtorlales
Universitarias Españolas nacional.

Esta editorial es miembro de la UNE, lo que garantiza la difusión y comercialización de sus publicaciones a nivel nacional e inter-

ISSN: $1988-0979$

I.S.B.N.: 978-84-9044-311-8 (Edición impresa)

I.S.B.N.: 978-84-9044-434-4 (Edición electrónica)

D.O.I.: http://doi.org/10.18239/alm_2021.13.00

D.L.: CU 248-2019

Composición: Compobell S.L.

Impresión: Gráficas Izquierdo

Hecho en España (U.E.) - Made in Spain (U.E.)

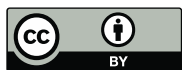

Esta obra se encuentra bajo una licencia internacional Creative Commons CC BY 4.0.

Cualquier forma de reproducción, distribución, comunicación pública o transformación de esta obra no incluida en la licencia Cretative Commons CC BY 4.0 solo puede ser realizada con la autorización expresa de los titulares, salvo excepción prevista por la ley. Puede Ud. acceder al texto completo de la licencia en este enlace: https://creativecommons.org/licenses/by/4.0/deed.es 


\section{ÍNDICE}

Presentación ..................................................................................

Gabino Marco Solera, Carmen María Montalbán Martínez y Antonio Ruiz Lucas

Las Cortes y la Constitución de Cádiz: contenidos sociales y esperanzas populares

Juan Sisinio Pérez Garzón

La Constitución de 1812

Enrique Belda Pérez-Pedrero

Guerra y revolución en La Mancha Ángel Ramón del Valle Calzado

El Partido de Alcaraz a finales del Antiguo Régimen

65 Carmen Hernández López y Francisco García González

"Napoleón emperador" y el destino del Partido de Almagro......... José Gregorio Cayuela Fernández

La Mancha, 1812: El partido judicial de Villanueva de los Infantes Lucía Crespo Jiménez

Representación y educación político-popular en las ceremonias y fiestas de proclamación y jura de la Constitución de 1812 en La Mancha

Carlos Chaparro Contreras

La crisis del Antiguo Régimen en La Mancha (1787-1808). El caso de Villanueva de los Infantes y su partido.... Carlos Javier Rubio Martínez 
Los manchegos que auparon a la "Pepa"

Enrique Jiménez Villalta

Almadén y la Constitución de Cádiz (1812-1814)

245

Julián Prior Cabanillas

El padre Agustín de Castro y la prensa periódica

273 Isidro Sánchez Sánchez 


\title{
EL PADRE AGUSTÍN DE CASTRO Y LA PRENSA PERIÓDICA
}

\author{
ISIDRO SÁNCHEZ SÁNCHEZ \\ COLABORADOR HONORÍFICO \\ Centro de Estudios de Castilla-La Mancha (UCLM)
}

El día 26 de septiembre de 1820, cuando habían pasado pocos meses del juramento de la Constitución de 1812 por parte del rey felón, era enterrado en el monasterio de El Escorial, el padre Agustín de Castro, instigador de la violencia, fustigador de liberales, periodista exaltado (editor y redactor de los periódicos Gazeta de la Junta Superior de La Mancha, Gazeta de la provincia de La Mancha y Atalaya de La Mancha en Madrid), adulador de la Constitución en La Mancha, azuzador del constitucionalismo y el liberalismo al regreso de Fernando VII a España, punta de lanza del absolutismo, "tan célebre por sus procacidades como por su fealdad".

El redactor de uno de los periódicos que proporcionaban la noticia de su muerte escribía que había bastantes datos para atribuir a la malicia la conducta del fraile pero no quería turbar la paz de su sepulcro y prefería creerle animado de un celo ciego e indiscreto en su actividad. Y concluía la información con estas palabras: "El ha muerto con tranquilidad después de haber visto triunfantes á los que él cooperó á perseguir, encarcelar y desterrar. Las víctimas cuya sangre se ha derramado no han levantado el grito contra él. Sirva este ejemplo para probar la diferencia entre los sentimientos de unos y otros" ${ }^{2}$. Los liberales en el poder tras la revolución de Riego no parecían querer pasar factura por las atrocidades cometidas contra ellos por el absolutismo en el sexenio anterior, con el rey inmisericorde a la cabeza.

1 P. Beroqui, "Apuntes para la historia del Museo del Prado. Cincuenta cuadros para Napoleón”, Boletín de la Sociedad Española de Excursiones, Madrid, (Marzo de 1931), p. 28.

2 "Noticias de la Península", en Diario Constitucional, Político y Mercantil de Barcelona, núm. 209 (9-10-1820), p. 1. En todos los casos he preferido respetar la ortografía original. 
Otro periódico, Diario Mercantil de Cádiz, se ocupaba también de la muerte del fraile y el redactor indicaba que su nombre pasaría a la posteridad en la historia de las calamidades de España, a las que contribuyó mucho "con su ciego é indiscreto celo" 3 . Pero la actividad del padre Castro, se recordaba, no había servido para nada: "vivió lo bastante para ver la inutilidad de sus esfuerzos contra las luces del siglo, y para esperimentar la generosidad de las víctimas de sus funestos consejos". Muy seguros parecían estar en el poder los liberales tras el golpe de fuerza de Rafael de Riego.

No sabemos mucho de la vida del padre Castro y hay que esperar la publicación de la monografía que anuncia Ángel Romera ${ }^{4}$, cuyos estudios son minuciosos, rigurosos y novedosos, para conocer la trayectoria vital y política del padre Castro. Nació en Tarancón (Cuenca) a mediados del siglo XVIII y al menos entre 1793 y 1794 fue regente de estudios en el monasterio Jerónimo de Nuestra Señora de la Esperanza de Segorbe (Castellón). Recuerda Romera que cuando era fraile del monasterio de San Lorenzo de El Escorial, predicó por La Mancha en poblaciones como Almagro o Villanueva de los Infantes. En 1804 era procurador general de la orden de San Jerónimo en España, el cargo más importante tras el prior, Alonso Baquero, y el secretario general, Francisco Avero ${ }^{5}$.

Ya producida la invasión francesa, en conexión con el reaccionario y absolutista Juan Bautista Erro Azpiroz, presidente de la Junta de La Mancha y superintendente de las Reales Minas de Almadén, dirigió la Gazeta de la Junta Superior de La Mancha (1812-1813), la Gazeta de la Provincia de La Mancha (1813) y su sucesora, Atalaya de La Mancha en Madrid (1813-15). Afirma Romera que aparte de sus indudables prejuicios ideológicos, su crueldad y su fanatismo, fue un periodista desigual pero bastante original, pues introdujo en el periodismo el estilo fresco, castizo y popularizante cervantino, imitado por otros periodistas, incluso liberales, como Félix Mejía: "Sus vehículos preferidos son la letrilla satírica al estilo quevediano, la décima y la sátira en prosa"6.

En 1816 aparecía como ministro honorario del Consejo de la reinstalada Suprema y General Inquisición en los siguientes términos: "Rmo.

3 “Madrid 30 de septiembre”, en Diario Mercantil de Cádiz, núm. 1.528 (9-10-1820), p. 2.

4 Á. Romera Valero, "La trayectoria periodística de Félix Mejía durante el Trienio Liberal. Primera parte: De La Colmena y la Periódico-Manía a El Cetro Constitucional (1820-1821)", en Cuadernos de Ilustración y Romanticismo, revista digital del Grupo de Estudios del Siglo XVIII, Cádiz, núm. 16 (2010).

5 Guía del estado eclesiástico seglar y regular, de España en particular, y de toda la Iglesia católica en general, para el año de 1804, Madrid, s. a., p. 323.

6 Á. Romera Valero, "La trayectoria periodística de Félix Mejía durante el Trienio Liberal. Primera parte: De La Colmena y la Periódico-Manía a El Cetro Constitucional (1820-1821)”, en Cuadernos de Ilustración y Romanticismo, revista digital del Grupo de Estudios del Siglo XVIII, Cádiz, núm. 16 (2010). 
P. M. Fr. Agustín de Castro, de la Orden de S. Gerónimo, con antigüedad, ausente" 7 . Igual cargo tuvo durante los años que siguieron hasta su muerte. Era el "pago" a su incitación a la violencia, a su absolutismo recalcitrante, a su defensa a ultranza del altar y el trono.

Dos ejemplos de su Atalaya pueden servir para ilustrar la toma de partido a favor de la violencia represora por parte del padre Castro. El primero relacionado con uno de los liberales más destacados, Bartolomé José Gallardo, que observaba los acontecimientos reaccionarios y fue capaz de anticipar lo que ocurriría. Eso le hizo clausurar la edición de La Abeja Madrileña el 7 de mayo de 1814: "Los redactores de este periódico están imposibilitados de proseguir en su publicación; porque se encuentran atacados de perlesía de resultas de cierto ayre seco, que sopla de Levante; viéndose precisados á mudar de ayres y tomar aguas termales" ". Dos días después la Atalaya de La Mancha en Madrid publicaba un epitafio por la muerte de la publicación de Gallardo que terminaba así: "Procúrate enmendar. Liberal fuerte, Mira que ya cercana está tu muerte" 9 .

El "aviso" es sólo un ejemplo escalofriante de la ideología excluyente de muchos serviles, según eran llamados por los liberales, en el comienzo de nuestra contemporaneidad. Si la advertencia al editor de La Abeja Madrileña, era seria, unas semanas después se escribían en el periódico del padre Agustín de Castro estas terribles palabras contra los liberales: "Mirad, Señor, que mientras ellos se rehacen y multiplican con la impunidad, los buenos se desalientan y se entibian. Tres ó quatro mil enemigos de V. M. mandados los unos a una hoguera, y los otros a una isla incomunicable, en nada disminuyen el número de vuestros vasallos. Yo bien penetro que sus cómplices os dirán que si se fuese a castigar a todos los del partido, era menester castigar a muchos miles, y cubrir de luto y de amargura un sin número de familias; pero traed a la memoria cuántos millares más fue menester herir para arrojar de España a los moriscos y a los judios, mucho menos perjudiciales que nuestros jacobinos, y con todo su expulsión se ejecutó, y desde entonces comenzamos a vivir felices y sin sustos" ${ }^{10}$. Es decir, para el fraile y para sus colaboradores el asesinato, el castigo, la represión, la expulsión de los diferentes, era el comienzo de la felicidad, actitud demasiado presente por desgracia en nuestra historia contemporánea.

$7 \quad$ Kalendario manual y guía de forasteros en Madrid para el año 1816, Madrid, 1816, p. 79.

8 "Aviso al pueblo de Madrid y al de todas partes, donde haya llegado este mal andante y mal-andado papel, llamado La Abeja Madrileña”, suplemento a La Abeja Madrileña del sábado 7 de mayo de 1814, p. 428.

9 M. G., "Á la difunta Abeja. Epitafio", Atalaya de La Mancha en Madrid, núm. 38 (9-51814), p. 309.

10 Atalaya de La Mancha en Madrid, núm. 92 (2-7-1814), pp. 755-756. 


\section{Historiadores E imágenes del padre CASTRo}

Quiero empezar con dos retratos del monje. Uno realizado en su época y publicado en 1826, a los pocos años de su muerte. Otro trazado hace poco tiempo por un gran historiador, Alberto Gil Novales, verdadero experto en el conocimiento del primer tercio del siglo XIX español.

Carlos Le Brun, ciudadano de los EE UU, publicó un libro con una serie de semblanzas de personajes que intervinieron en la llamada Revolución española, profundizando en la dicotomía servil-liberal e intentando contestar a la pregunta de por qué la revolución triunfó en EE UU y fracasó en España ${ }^{11}$. Una de las biografías era, precisamente, la del padre Castro y merece la pena detenerse en ella para tratar de entender la imagen con la que era presentado por el liberalismo reformador, en este caso la línea ideológica defendida por Le Brun.

Caracterizaba al clérigo como periodista servil, que escribía "á lo frayle, es decir servil y fanáticamente", aunque sin creer en lo que escribía, ni en el Rey, ni en Dios, pues estaba sólo atento a sus intereses. Era el "padrecito", indicaba, un pájaro de cuenta pues todo lo que convenía a "sus fines, su negocio ó sus comodidades, era religión para él”. Merece la pena recordar diversos párrafos de la biografía en los que se incidía en la utilización de la religión para sus objetivos: "resistir la constitución, porque con libertad no hay monges, ni grandes riquezas, ni misas, ni sacaliñas, es religión. Inventar, para hacer odiosas las cortes una constitución secreta (se supone republicana) y decir la habia hecho en el congreso, y esto sin que nadie, sino él, lo hubiese sentido, y mandarla imprimir y publicar por todas las esquinas, es religión". Esas actividades consiguieron, según Le Brun, que Fernando VII le pagase, "con los honores de la suprema y con quarenta mil reales del pico, que para un monge geronimo, que regüelda siempre de abito, y luego sus buenas siestas y letras gordas". Desde luego, su presencia en la Inquisición está demostrada pero es más difícil saber si recibió cantidad económica como recompensa a sus desvelos absolutistas, aunque diversos autores citan cantidades diferentes.

11 C. Le Brun, Retratos políticos de la revolución de España, de los principales personages que han jugado en ella, muchos de los quales están sacados en caricaturas por el ridículo en que ellos mismos se habian puesto, quando el retratista los iba sacando; con unas observaciones polí ticas al fin sobre la misma y la resolución de la question de por qué se malogró esta y no la de los Estados-Unidos, Filadelfia, s. i., 1826, pp. 252-253. En la Biblioteca Nacional de España se conserva el manuscrito de esta obra, con título similar y la frase en portada "Escrito por un emigrante español en Filadelfia" (BNE, MSS/2553). Un análisis del libro se puede ver en F. Cuevas Cervera, "La Historia a través de sus personajes: Sátira política, biografía y reconstrucción histórica en los Retratos politicos de la Revolución de España de Carlos Le Brun”, en Cuadernos de Ilustración y Romanticismo, Cádiz, núm. 11 (2003), pp. 149-178. 
También mencionaba el escritor estadounidense la tremenda contradicción entre un Castro violento, fanático y fustigador de la Constitución y otro anterior, adulador de la misma y defensor de la libertad: "También es religión contradecirse, quando se llegó en Almagro á inflamar algo el deseo de la libertad, que creyó ya el padre podía cuajar la constitución, y predicó a favor de ella, ponderándola, comparándola con los evangelios, y poniéndola por encima de las nubes; porque entonces no habría yá conventos, y era menester ver, si las Cortes ó el gobierno le daban un destinito". Y terminaba la biografía con una alusión a su muerte en 1820, cuando llegaba otra vez la libertad a España, que era recordada por el escritor nacionalizado estadounidense con las siguientes palabras: "El pobre Atalaya parece haberse muerto de miedo de la libertad. Al nacer ella en España el año de veinte, murió él. Parece que el grito de libertad lo mató. ¿Qué había de hacer? ¡Cómo que la había calumniado tanto!".

Por su parte, Alberto Gil Novales limita la biografía prácticamente a la labor de Castro en su Atalaya de La Mancha en Madrid y a los conflictos generados durante la edición ${ }^{12}$. Primero indica que probablemente fue el autor de una carta crítico burlesca referida a los periodistas ${ }^{13} \mathrm{y}$ después trata la denuncia de José Mor de Fuentes por el contenido del número siete de su Atalaya. En él, José Mor y Pano, sus verdaderos apellidos, era calificado como racionero, "esto es, hombre que á veces se ha mantenido por ese mundo de Dios de raciones sacadas fuera de ordenanza, cuando iba bagando, huyendo igualmente de franceses y españoles". También se recordaba su inclinación intelectual para hacer coplas de ciegos; su vocación de conciencia, murmurar "mazorralmente, es decir, de forma ruda y grosera; y "su todo total en toda su totalidad, escribir disparates á troche y moche"14. José Mor era atacado en el marco de la reacción en la Atalaya a las críticas que los frailes recibían por aquellos tiempos y el número fue secuestrado por la Junta de Censura de Madrid, con la acusación de calumnias e injurias ${ }^{15}$. Recuerda también Gil Novales que por su polémica con El Ciudadano en julio y agosto de

12 A. Gil Novales, Diccionario biográfico español (1808-1833). De los orígenes del liberalismo a la reacción absolutista, Madrid, Fundación Mapfre, 2010, 3 vols. Biografía en tomo I, p. 675. Autor también de la obra titulada Prensa, guerra y revolución. Los periódicos españoles durante la Guerra de la Independencia, Madrid, CSIC, 2009.

13 F. A. de C., Carta critico burlesca que dirige F. A. de C. á un R.R., en la que se demuestra la prodigiosa ciencia de los periodistas iluminados de C. y M., y los grandes milagros que han obrado con sus finísimas y liberales plumas, Cádiz, Imprenta de Antonio de Murguía, 1812.

14 Atalaya de La Mancha en Madrid, núm. 7 (3-8-1813), p. 51.

15 El fraile respondió al secuestro con su Dictamen de la Junta Censoria de esta capital de Madrid sobre el número séptimo de la Atalaya de la Mancha, delatado por D. Josef Mor de Fuentes, y contestación del Autor a la Censura, Madrid, Imp. de Francisco de la Parte, 1813. 
1813 el fraile fue detenido y llevado a la cárcel el día 9 de noviembre, aunque debido a la enfermedad que padecía quedó retenido en su casa.

Finalmente indica que en el número repartido en 12 de mayo de 1814 publicó la relación de liberales presos e hizo que los ciegos la vocearan como la "lista de los traidores". En ese mismo número se recuerdan las inserciones en números anteriores en las que se citaban y reproducían artículos de una Constitución secreta, que daban pie a todo tipo de acusaciones contra los liberales. Conseguido el propósito de su puesta en la cárcel, en la Atalaya se concluía la especie de artículo editorial con esta frase: "Españoles, alabad y bendecid al Señor. Nuestra patria es ya feliz : ya reyna FERNANDO" 16 . Y se insertaban unas letrillas para atacar a los liberales con las recurrentes frases "No le arriendo la ganancia", en una primera serie, y "Le cayó la lotería", en una segunda. Ejemplo de las dos series, en las que se observa un regocijo no disimulado por la represión a los liberales, son estos:

\author{
"Al liberal exaltado. \\ Partidario del francés, \\ Que el mas atrevido es \\ En la Regencia apoyado; \\ Por cuyo medio ha logrado \\ Un destino su arrogancia: \\ No le arriendo la ganancia”. \\ "Al Redactor mentiroso. \\ En este arte general, \\ Que al español mas leal \\ Tituló de sedicioso. \\ Por infame y pernicioso \\ En tan culta Monarquía \\ Le cayó la lotería.
}

$\mathrm{Al}$ que es del anterior hijo.

Llamándose en realidad

Conciso, en decir verdad,

$\mathrm{Y}$ en no decirla prolixo.

Que en su lengua contradixo

Al Rey la Soberanía:

Le cayó la lotería”.

16 “Españoles”, Atalaya de La Mancha en Madrid, núm. 41 (12-5-1814), pp. 327-331. 
En general, la historiografía absolutista primero y liberal conservadora después trató de transmitir la imagen de un padre Castro patriota, católico y fernandino, obviando sus salidas de tono, su fanatismo y sus apelaciones a la violencia. Sin embargo, la liberal progresista le presentó tradicionalmente como un clérigo recalcitrante, absolutista, furibundo y ultra-realista.

La historiografía liberal progresista, como ya he escrito, ha tratado a Castro de manera rigurosa, afeando su anticonstitucionalismo e indicando la virulencia de sus escritos. En Ciudad Real, donde el fraile inició su cambio de postura de constitucionalista a absolutista, Joaquín Gómez ${ }^{17}$ hacía referencia a la Junta Superior de La Mancha en estos términos: "La Junta llamada de la Mancha, sin casi tener manchegos y de la que tanto pudiera decir publicó la Constitución en dicho Villanueva de los Ynfantes”. Es una pena que no dijera más en su mala historia de Ciudad Real, a pesar de lo mucho que decía saber ${ }^{18}$. Lo que si mostraba era la gran contradicción de un padre Castro predicando a favor de la Constitución "en un sentido muy opuesto a lo que luego escribió escandalosamente en el periódico que tituló Atalaya de la Mancha; pues en el púlpito explicó con entusiasmo máximas avanzadas muy liberales, y el periódico Atalaya no se saciaba de estilo más servil".

Por recordar a un autor de prestigio se puede hacer mención a Modesto Lafuente. Periodista, historiador y político liberal, se ocupaba en su Historia de España del regreso de Fernando VII y observaba cómo eran los clérigos los que más atizaban el odio al liberalismo y los que en lugar de aconsejar indulgencia llamaban a la persecución y pedían venganza. Se puede recordar un párrafo de su visión, en la que nuestro fraile ocupa lugar preferente por su virulencia: "De los claustros salían furibundas y sangrientas representaciones: los ex-diputados eclesiásticos como Ostolaza y Creux, delataban á sus antiguos compañeros en las cortes; el padre Castro, monje del Escorial, en un periódico La Atalaya de La Mancha, publicaba escritos llenos de hiel, que respiraban furor sanguinario; y otro clérigo, que por adular al rey exageradamente no

17 Joaquín Gómez, político y escritor, fue diputado suplente por el reino de Aragón en 1813, cuando era regidor constitucional de Zaragoza. En 1836 fue elegido diputado por Ciudad Real, donde escribió una historia de La Mancha.

18 J. Gómez Fernández, Historia del río Guadiana, de Alarcos, Consuegra, Oreto, Miguelturra y otras poblaciones de la Mancha: de la ciudad de Ciudad Real, de importantes acontecimientos; de las Templarios, Calatravas vieja y nueva, y de sus treinta Maestres, Extracto histórico de España, y lista de sus reyes, casamientos y muertes, Ciudad Real, JCCLM - Ayuntamiento de Ciudad Real, 2010, pp. 152-153. Se mantuvo manuscrita desde su elaboración hasta que el cronista oficial de Ciudad Real, Manuel López Camarena, se empeñó en su edición. Con un elevado coste económico, fue patrocinada por el Ayuntamiento de Ciudad Real y por la Junta de Comunidades de Castilla-La Mancha. 
reparaba en hacerse sacrílego y blasfemo, imprimía un panegírico con el título extravagante de: Triunfos reciprocos de Dios y Fernando VII"19.

Otro autor, Alfredo Opisso, escribía en su Historia de España sobre el terror que se impuso en España con la vuelta del rey felón. Personas de los sectores sociales más desfavorecidos, jaleados machaconamente por el absolutismo, rodeaban las cárceles donde estaban presos los liberales y cantaban cosas como esta: "Murieron los liberales, // Murió la Constitución // Porque viva el Rey Fernando // La Patria y la religión”. Y a ese ambiente de terror colaboraron los periódicos absolutistas, como el del padre Castro, "ex liberal de lo más exaltado" ${ }^{20}$. Por todas partes se propagaba la idea de que los liberales formaban una banda de asesinos partidarios de Napoleón, que querían acabar con el rey y proclamar la República, como en Francia.

Manuel Tuñón de Lara, maestro de historiadores, también se ocupaba de la reacción fernandina en 1814 y hablaba en 1968, desde el exilio francés, de clérigos delatores, de órdenes religiosas con miembros que rivalizaban en actitudes alejadas del Evangelio, de curas participantes en la brutal restauración del viejo régimen. Y en ese marco, tachaba de libelo al periódico del padre Castro, donde se pedía el exterminio, como ya se ha visto, de los liberales ${ }^{21}$. Atalaya de La Mancha en Madrid fue, en definitiva, uno de los medios propagandísticos más eficaces para preparar lo que el historiador Juan Sisinio Pérez Garzón denomina primer golpe de Estado de la historia contemporánea española ${ }^{22}$.

$* * *$

También se pueden recordar las imágenes del padre Castro que proporcionaban distintos historiadores de la prensa, empezando por Juan Pedro Criado Domínguez, que le trataba en 1892 de muy reverendo y responsable de una crítica punzante y acerada ${ }^{23}$. Con una imagen positiva era presentado también en 1894 por Eugenio Hartzenbusch Hiriart, sin crítica a su actuación, como vivo defensor de Fernando VII, de estilo

19 M. Lafuente, Historia general de España desde los tiempos primitivos hasta la muerte de Fernando VII, Barcelona, Montaner y Simón, 1880, tomo V, p. 320.

20 A. Opisso, Historia de España y de las repúblicas Latino-Americanas, Barcelona, Editorial Gallach, s. a., tomo XX, p. 22.

21 M. Tuñón de Lara, El hecho religioso en España, París, Éditions de la librairie du Globe, 1968, pp. 76-77.

22 J. S. Pérez Garzón, Las Cortes de Cádiz. El nacimiento de la nación liberal (1808-1814), Madrid, Síntesis, 2007, pp. 404-407.

23 J. P. Criado Domínguez, Antigüedad e importancia del periodismo español. Notas históricas y bibliográficas, Madrid, Sociedad Editorial San Francisco de Sales, 1892, p. 40. 
fuerte y polemista con los liberales ${ }^{24}$. Asimismo, el hijo de Juan Eugenio Hartzenbusch Martínez, autor de Los amantes de Teruel, destacaba la ayuda que tuvo Castro en otros religiosos, como el franciscano Manuel Gómez Negrete, el capellán Sinueva o el padre mercedario Fr. Manuel Martínez ${ }^{25}$.

Una década después era citado por Manuel Ossorio y Bernad como apasionado defensor de Fernando VII y absolutista, además de "objeto de numerosas persecuciones" 26 . Por otra parte, el periódico Atalaya de La Mancha en Madrid, según afirmaba, era una de las publicaciones "que mejor caracterizan la época de apasionamientos y odios en que se publicó”.

Desde una posición liberal conservadora, comprensiva en cierto modo con el absolutismo, Manuel Gómez Imaz calificaba en 1910 a la Atalaya como periódico batallador y le prestaba a Castro un carácter tenaz, una muy firme voluntad, con una educación claustral de teólogo y dialéctico. Con esas armas "diestramente esgrimidas", escribía, peleó "contra la falange constitucional, fustigándola con agudísimos chistes y donaires, refutando las doctrinas afrancesadas que no cabían ni en la inteligencia, ni en la religiosidad, ni en el corazón de aquel fraile tal español y amante de su patria" ${ }^{27}$. A continuación reproducía una parte importante del número prospecto de la Atalaya de La Mancha en Madrid y las letrillas del número ya citado correspondiente al 12 de mayo de 1814. En fin, Gómez Imaz escribía sobre el "batallador y fogoso Fr. Agustín de Castro", uno de los componentes del bando antirreformista, "que era el partido nacional que defendía las antiguas tradiciones en punto a libertades patrias y principios religiosos" 28 .

Cien años después de la primera restauración borbónica, en 1914, Luis del Arco y Muñoz editaba su libro sobre los periódicos en la Guerra de Independencia y se ocupaba del fraile, de su publicación periódica madrileña y de diferentes reediciones ${ }^{29}$. El bibliotecario y catedrático de instituto de Geografía e Historia, que indicaba ciertas carencias de la

24 E. Hartzenbusch Hiriart, Apuntes para un catálogo de periódicos madrileños desde el año 1661 al 1870, Madrid, Est. Tip. Sucesores de Rivadeneyra, 1894, p. 21.

25 Doctor, catedrático de Teología en la Universidad de Valladolid, predicador, antiliberal furibundo. Además de redactor de la Atalaya de La Mancha en Madrid, dirigió El Restaurador en 1823 y 1824 . Por sus servicios, Fernando VII le puso al frente de la diócesis de Málaga.

26 M. Ossorio y Bernard, Ensayo de una catálogo de periodistas del siglo XIX, Madrid, Imp. y Lit. de J. Palacios, 1903, p. 80.

27 M. Gómez Imaz, Los periódicos durante la Guerra de la Independencia (1808-1814), Madrid, Tip. de la Revista de Arch., Bibl. y Museos, 1910, pp. 57-62.

28 M. Gómez Imaz, Los periódicos..., p. 27.

29 L. del Arco y Muñoz, La prensa periódica en España durante la Guerra de la Independencia (1808-1814). Apuntes bibliográficos, Castellón, Tip. Joaquín Barberá, 1914, pp. 140-141 y 172-173. 
obra de Gómez Imaz y no compartía su entusiasmo por el fraile, calificaba a la Atalaya como "iracunda en sus escritos y defensora acérrima del absolutismo". Del Arco afirmaba que el lenguaje violento que utilizaba y sus indiscreciones llegaron a molestar incluso a Fernando VII y que su actividad ayudó a la prohibición, el 25 de abril de 1815, de todos los periódicos políticos que se editaban en España ${ }^{30}$.

Con un gran salto temporal, ya durante el Franquismo, Pedro Gómez Aparicio veía al clérigo como una especie de paladín contra el mal, con cierta fama de teólogo, aunque, afirmaba, destacó como polemista acerado y agresivo. El monje, que recomendaba la eliminación física de los liberales, aparecía para el periodista franquista como víctima de la persecutoria intransigencia liberal. En cuanto a su labor periodística Gómez Aparicio la presentaba así: "Pocas plumas de aquel tiempo superan en ingenio, desenvoltura y donaire a la del Padre Castro, que con igual facilidad escribia en verso que en prosa”. Pero su estilo era sencillo, incisivo y mordaz, aunque, frecuentemente, destemplado y sin altura" 31 . Es preciso recordar que Gómez Aparicio se forjó como periodista en el diario católico El Debate, que desde 1938 a 1944 fue subdirector de la Agencia EFE y director desde ese año a 1959, presidió la Asociación de la Prensa de Madrid, recibió numerosas condecoraciones y que durante el primer Franquismo fue uno de los referentes ideológicos mejor valorado por el Régimen.

Y, por citar un último ejemplo más cercano en el tiempo, se puede recordar a María Cruz Seoane que calificaba al monje de San Jerónimo de "furibundo ultrarealista". Cuando los clérigos absolutistas ya estuvieron seguros de que el proceso reaccionario era irreversible se ensañaron con los caídos liberales, se convirtieron en vehículos de la delación y de la persecución, "fraguando fantásticas historias de pretendidas conspiraciones republicanas" 32 .

30 "EI REY nuestro Señor se ha servido expedir con fecha de 25 de1 corriente el decreto que sigue: Habiendo visto con desagrado mio el menoscabo del prudente uso que debe hacerse de la imprenta, que en vez de emplearla en asuntos que sirvan a la sana ilustración del publico, ó á entretenerle honestamente, se la emplea en desahogos y contestaciones personales, que no solo ofenden a los sugetos contra quienes se dirigen, sino a la dignidad y decoro de una nación circunspecta, á quien convidan con su lectura; y bien convencido por Mi mismo de que los escritos que particularmente adolecen de este vicio son los llamados periódicos y algunos folletos, provocados por ellos, he venido en prohibir todos los que de esta especie se dan a luz dentro y fuera de la corte; y es mi voluntad que solo se publiquen 1a gaceta y diario de Madrid. Tendreislo entendido, y dispondreis lo necesario a su cumplimiento; encargando de nuevo a quien corresponda que se observen religiosamente las leyes que prescriben el examen que debe hacerse de las demas obras que hayan de darse a la prensa. Esta rubricado. = A D. Pedro Cevallos”. En Gaceta de Madrid, núm. 51 (27-4-1815), p. 438.

31 P. Gómez Aparicio, Historia del periodismo español. Desde la GACETA DE MADRID (1661) hasta el destronamiento de ISABEL II, Madrid, Editora Nacional, 1967, pp. 113-115.

32 M. C. Seoane, Historia del periodismo en España. 2. El siglo XIX, Madrid, Alianza, 1983, pp. 57-58. 


\section{RETRATOS EN LA PRENSA DEL FRAILE EXALTADO}

Afirma Manuel Revuelta que tras el traslado de las Cortes a Madrid se desarrolló una campaña realista importante, cada vez mas audaz y agresiva, desplegada principalmente por eclesiásticos: "El jerónimo Fr. Agustín de Castro y el mercedario Fr. Manuel Martínez acometían a los liberales con violencia y gracejo en La Atalaya de La Mancha; los sacerdotes Molle y Senalde colaboraban en el Procurador General de la Nación y del Rey; el cura Vinuesa reeditaba el Preservativo de Vélez y el cura de Carranque, Narciso Español, escribía La Iglesia en triunfo contra la nueva filosofía" ${ }^{33}$. Fueron diversos los medios empleados para alabar a Fernando VII y denostar a los liberales pero la prensa fue uno de los principales, con curas y frailes a la cabeza.

En los agitados años de la Guerra de independencia hubo, como se sabe, una verdadera eclosión periodística. Entre las publicaciones periódicas absolutistas El Procurador General de la Nación y del Rey (Cádiz, 1812-1813 y Madrid, 1814-1815), que desde junio de 1814 se tituló El Procurador General del Rey y de la Nación) y Atalaya de La Mancha en Madrid fueron quizá las más influyentes y beligerantes. El título del primero es muestra de su contenido, aunque hay que añadir su apuesta decidida por la religión para completar la que se convertiría en triada fundamental del absolutismo y luego del carlismo. Los escritos en contra del liberalismo y el constitucionalismo, reproducidos por la mayoría de sus correligionarios, alcanzaron importante influjo, aunque siempre en sectores reducidos. Se manifestaba un apoyo sin fisuras a Fernando VII, se defendía a ultranza la religión católica, contaminada por las nuevas filosofías, y se protegía, según se afirmaba, el "verdadero" espíritu español frente a las ideas y las costumbres extranjeras.

El segundo, como se verá más adelante, fue uno de los más radicales y exaltados pues bajo la batuta del padre Agustín de Castro desarrolló una defensa cerrada de ideas como las ya citadas y llegó a adquirir una especie de "frenesí histérico", en acertada expresión de Javier Herrero, en los meses de la restauración borbónica ${ }^{34}$. Apareció a comienzos de julio de 1813 y se puede recordar una referencia a su salida con la frase siguiente: "Como ya se derramó por esta capital un prospecto que abra-

33 M. Revuelta González, "La Iglesia española ante la crisis del Antiguo Régimen (180833)", en Vicente Cárcel Ortí, Historia de la Iglesia en España. V. La Iglesia en la España contemporánea (1808-1975), Madrid, Biblioteca de Autores Cristianos, 1979, p. 65.

$34 \mathrm{~J}$. Herrero, Los orígenes del pensamiento reaccionario español, Madrid, Alianza, 1988, pp. 387-388. La primera edición apareció en Madrid en 1971 de la mano de la editorial Cuadernos para el Diálogo, que en 1973 publicó una segunda edición. Hoy el excelente libro es todo un clásico para la comprensión del pensamiento reaccionario español. 
za el plan de dicho periódico, se considera bastante decir que la religión, el gobierno y el orden social son los principales objetivos de su autor" 35 .

Ya en la época de edición de Atalaya de La Mancha en Madrid se ponían de manifiesto en la prensa liberal, con meridiana claridad, las inclinaciones reaccionarias del fraile, aunque no era muy conocido su papel en Gazeta de la Junta Superior de la Mancha a favor de la constitución de 1812. Un artículo comunicado publicado en El Redactor General, editado en Cádiz, se dirigía al "M. R. P. Fr. Gerundio de Ciudad Real, ex-gacetero de La Mancha, actual Atalaya en Madrid, procurador de los serviles, etc. etc. etc." ${ }^{36}$. Y se trazaba un retrato en un crítico soneto en el que además de servil era identificado como pancista y tragaldabas:
"Continuo coro, ayuno, y disciplina
Dexas gozoso, huyendo del contrario;
Y de todo tu insigne santuario,
Tan solo dexar sientes la cocina.
Vas á La Mancha, y tu aficcion te inclina
A ser con tu papel estrafalario
(que llamaste Gaceta) el partidario
Mas eficaz de la servil doctrina.
A Madrid tornas, y hecho un Diocleciano
En tu Atalaya todo lo promueves,
Por no dexar al libre hueso sano;
Y pues tanto camino á hollar te atreves,
Huella un poco el de ser un buen cristiano, Y un silenciosos monge como debes."

Igualmente, ya en aquellos años se puso de manifiesto su chaqueteo, su conducta cambiante, su actitud "cambia colores", como se decía en la época. Pasó, como ya se ha visto, de enfervorecido defensor de la Constitución de 1812 a uno de sus más violentos detractores. Por eso en El Diario de Madrid se escribía lo siguiente en agosto de 1813: "Como vmd., padre mío, no ha jugado siempre a una sola carta, era algo difícil conocer al cabo su intención" 37 .

De 1820, aparte de las noticias de la muerte del padre Castro ya citadas, se puede recordar una referencia en la crítica y satírica publicación La Periódico-Manía. El diario El Conservador se editó en Madrid desde

35 Gazeta de Madrid baxo el Gobierno de la Regencia de las Españas, Madrid, núm. 19 (207-1813), p. 204.

36 J. F., “Artículo comunicado", El Redactor General, Cádiz, núm. 809 (1-9-1813), p. 4.

37 "Al editor del periódico titulado la Atalaya de la Mancha", en Diario de Madrid, núm. 239 (27-8-1813), p. 257. 
marzo hasta septiembre de 1820 y cuando La Periódico-Manía se ocupaba de ella daba noticia de un matrimonio entre un "cierto Procurador, con una tal doña fulana Atalaya" 38 , en referencia a los dos periódicos absolutistas de notable influjo. Aunque eran viejos y desconfiaban en tener descendencia, hicieron una novena al glorioso San Ramón-Nonato, se escribía, y lograron que el cielo les favoreciese con un precioso niño, al que dieron por nombre El Conservador, "periódico como sus padres; de las mismas inclinaciones, las mismas ideas, la misma instrucción, la misma elocuencia: todo lo mismo. El Conservador ¿¿de qué? No se que te diga Antón, // tú traes el hocico untado, // y á mí me falta un lechón”. Y afirmaba el redactor que El Conservador caminaba sólo si quería conservar el sistema de antaño, del Antiguo Régimen, aunque es verdad que podría encontrar adeptos en el cesantismo, nombre dado en el periódico a todos los que antes de la Niña bonita (La Constitución) figuraban y después ya no figuraban. Se iniciaba en estos años una línea de crítica a determinadas posiciones conservadoras españolas, muy reaccionarias, excesivamente penetradas de religión e, incluso, de variados elementos del absolutismo.

También en 1820, tras su muerte, otro periódico recordaba al monje y lo trataba de "cerdoso y asaz mugriento, que en menos que lo dijo forjó la Constitución secreta, la República de las Cortes y hasta las cucardas y ropones consulares", en alusión a las acusaciones que vertió en su Atalaya en contra de los liberales ${ }^{39}$. También, de forma irónica, el diario barcelonés llegaba a calificarle como docto y agudísimo Varón y se escribía que había recibido la Constitución de forma anónima, manera diferente al padre Tragia, al que le había sido comunicada, según llegó a afirmar, en confesión ${ }^{40}$.

La figura del padre Castro ha tenido presencia abundante en la prensa periódica, sobre todo en el siglo XIX, y ha sido presentada con una serie de muy diversos calificativos. La selección que aparece en el cuadro siguiente recoge términos empleados muchas veces sin que su autor pueda ser identificado, aunque en algunas es posible, como en el caso de "Furibundo atleta ultra-realista", utilizado por Mesonero Romanos en la edición por entregas de su obra Memorias de un setentón en la revista

38 La Periódico-Manía, núm. 3 (1820), pp. 6-7. Sobre este y otros periódicos de Félix Mejía ver el artículo citado de Á. Romera Valero, "La trayectoria periodística de Félix Mejía durante el Trienio Liberal...”.

39 Espoleta, "Noticias particulares de Barcelona. Observaciones a la Camándula", Diario Constitucional, Político y Mercantil de Barcelona, núm. 215 (15-10-1820), pp. 3-4.

40 Ver Un amante de la Religión, del Rey y de la Patria, Constitución fundamental y secreta de los libertadores del genero humano inserta en los números 1, 2, 3, 4, 5, 6, 7 y 41 de la Atalaya de la Mancha que reunida / publica para instrucción y desengaño del pueblo español un Amante de la Religión, del Rey y de la Patria, Málaga, Imp. de Martínez, 1814. 
La Ilustración Española y Americana. En la primera columna figuran las denominaciones, palabras o frases, con las que se cita al padre Castro, en la segunda el título y otros datos de la publicación periódica y en la tercera su carácter.

\begin{tabular}{|c|c|c|}
\hline PADRE CASTRO & $\begin{array}{l}\text { TÍTULO Y DATOS DE LA } \\
\text { PUBLICACIÓN }\end{array}$ & $\begin{array}{l}\text { CARÁCTER DE } \\
\text { LA PUBLICACIÓN }\end{array}$ \\
\hline R. P. manchego & $\begin{array}{l}\text { El Conciso, } \\
\text { Cádiz, núm. } 6 \text { (6-12-1812), p. } 8\end{array}$ & Liberal \\
\hline $\begin{array}{l}\text { Flor de los serviles } \\
\text { gaceteros }\end{array}$ & $\begin{array}{l}\text { El Redactor General, } \\
\text { Cádiz, núm. } 597 \text { (31-1-1813), p. } 1 .\end{array}$ & Liberal \\
\hline $\begin{array}{l}\text { M. R. P. Fr. Gerundio } \\
\text { de Ciudad Real }\end{array}$ & $\begin{array}{l}\text { El Conciso, } \\
\text { Cádiz, núm. } 5 \text { (5-3-1813), pp. } 1 \text { a } 5\end{array}$ & Liberal \\
\hline $\begin{array}{l}\text { P. gacetero de La } \\
\text { Mancha }\end{array}$ & $\begin{array}{l}\text { Gazeta Marcial y Política de } \\
\text { Santiago, } \\
\text { Santiago de Compostela, núm. } 43 \\
(1-5-1813), \text { p. } 427\end{array}$ & Liberal \\
\hline $\begin{array}{l}\text { Gacetero de La } \\
\text { Mancha }\end{array}$ & $\begin{array}{l}\text { El Ciudadano por la Constitución, } \\
\text { La Coruña, núm. } 72 \text { (5-5-1813), p. } 452\end{array}$ & Liberal \\
\hline Padre gacetero & $\begin{array}{l}\text { El Procurador General de la Nación } \\
\text { y del Rey, } \\
\text { Cádiz, no } 239 \text { (27-5-1813), p. } 1.969\end{array}$ & Absolutista \\
\hline Padre gacetero & $\begin{array}{l}\text { Atalaya de La Mancha en Madrid, } \\
\text { Madrid, } \mathrm{n}^{\circ} \text { prospecto (4-7-1813), p. } 1\end{array}$ & Absolutista \\
\hline $\begin{array}{l}\text { Padre gacetero de } \mathrm{La} \\
\text { Mancha } \\
\text { Su paternidad }\end{array}$ & $\begin{array}{l}\text { El Conciso, } \\
\text { Cádiz, no } 17 \text { (11-7-1813), p. } 6\end{array}$ & Liberal \\
\hline $\begin{array}{l}\text { Ex-gacetero de La } \\
\text { Mancha } \\
\text { Su paternidad Panza }\end{array}$ & $\begin{array}{l}\text { El Conciso, } \\
\text { Cádiz, no } 16 \text { (16-8-1813), p. } 2\end{array}$ & Liberal \\
\hline Religiosísimo religioso & $\begin{array}{l}\text { El Conciso, } \\
\text { Cádiz, no } 29 \text { (29-8-1813), p. } 8\end{array}$ & Liberal \\
\hline $\begin{array}{l}\text { Fr. Gerundio de } \\
\text { Ciudad Real, } \\
\text { Ex-gacetero de La } \\
\text { Mancha, } \\
\text { Atalaya en Madrid } \\
\text { Procurador de los } \\
\text { serviles }\end{array}$ & $\begin{array}{l}\text { El Redactor General, } \\
\text { Cádiz, núm. } 809 \text { (1-9-1813), p. } 4\end{array}$ & Liberal \\
\hline Padre de la risa & $\begin{array}{l}\text { Diario de Madrid, } \\
\text { Madrid, no } 309 \text { (6-11-1813), p. } 556\end{array}$ & Liberal moderado \\
\hline
\end{tabular}




\begin{tabular}{|c|c|c|}
\hline PADRE CASTRO & $\begin{array}{l}\text { TÍTULO Y DATOS DE LA } \\
\text { PUBLICACIÓN }\end{array}$ & $\begin{array}{l}\text { CARÁCTER DE } \\
\text { LA PUBLICACIÓN }\end{array}$ \\
\hline Padre atalayero & $\begin{array}{l}\text { El Amigo del Pueblo, } \\
\text { Madrid, núm. } 32 \text { (13-11-1813), p. } 256\end{array}$ & Liberal \\
\hline Padre Atalaya & $\begin{array}{l}\text { Diario de Juan Verdades, } \\
\text { Madrid, nº, } 7 \text { (16-1-1814), p. } 28\end{array}$ & Constitucionalista \\
\hline Padre Atalaya & $\begin{array}{l}\text { Atalaya de La Mancha en Madrid, } \\
\text { Madrid, n } 91 \text { (1-7-1814), p. } 748\end{array}$ & Absolutista \\
\hline $\begin{array}{l}\text { Padre gacetero de La } \\
\text { Mancha }\end{array}$ & $\begin{array}{l}\text { Atalaya de La Mancha en Madrid, } \\
\text { Madrid, no } 250 \text { (29-12-1814), p. } \\
2.028\end{array}$ & Absolutista \\
\hline Padre Atalaya & $\begin{array}{l}\text { Exacto Diario en La Coruña, } \\
\text { La Coruña, núm. } 1 \text { (1-1-1815), p. } 6\end{array}$ & Absolutista \\
\hline Padre Atalaya & $\begin{array}{l}\text { Atalaya de La Mancha en Madrid, } \\
\text { Madrid, n } n^{\circ} 17 \text { (24-2-1815), p. } 129\end{array}$ & Absolutista \\
\hline Fanático e ignorante & $\begin{array}{l}\text { El Constitucional, } \\
\text { Madrid, } \mathrm{n}^{\circ} 415 \text { (27-6-1820), p. } 3 .\end{array}$ & Liberal \\
\hline Padre Atalaya & $\begin{array}{l}\text { Miscelánea de Comercio, Política y } \\
\text { Literatura, } \\
\text { Madrid, n }{ }^{\circ} 187 \text { (3-9-1820), p. } 4\end{array}$ & Liberal moderado \\
\hline Fray & $\begin{array}{l}\text { El Universal, } \\
\text { Madrid, } \mathrm{n}^{\circ} 115 \text { (3-9-1820), p. } 426\end{array}$ & Liberal moderado \\
\hline Injurioso & $\begin{array}{l}\text { Miscelánea de Comercio, Política y } \\
\text { Literatura, } \\
\text { Madrid, n }{ }^{\circ} 219 \text { (5-10-1820), p. } 3\end{array}$ & Liberal moderado \\
\hline Cerdoso y mugriento & $\begin{array}{l}\text { Diario Constitucional, Político y } \\
\text { Mercantil de Barcelona, } \\
\text { Barcelona, } \mathrm{n}^{\circ} 215 \text { (15-10-1820), p. } 3\end{array}$ & Liberal exaltado \\
\hline Padre Atalaya & $\begin{array}{l}\text { Nuevo Diario de Madrid, } \\
\text { Madrid, } \mathrm{n}^{\circ} 89 \text { (30-4-1821), p. } 372\end{array}$ & Liberal moderado \\
\hline $\begin{array}{l}\text { Apóstol del } \\
\text { despotismo }\end{array}$ & $\begin{array}{l}\text { Diario Constitucional, Político y } \\
\text { Mercantil de Barcelona, } \\
\text { Barcelona, } \mathrm{n}^{\circ} 78 \text { (19-3-1822), p. } 2\end{array}$ & Liberal exaltado \\
\hline Furibundo & $\begin{array}{l}\text { La América, } \\
\text { Madrid, nº } 14 \text { (24-9-1857), p. } 9\end{array}$ & Liberal Progresista \\
\hline Célebre & $\begin{array}{l}\text { Revista de España, } \\
\text { Madrid, n } 20 \text { (Noviembre de 1868), } \\
\text { p. } 620\end{array}$ & $\begin{array}{l}\text { Liberal } \\
\text { Conservador }\end{array}$ \\
\hline Sanguinario & $\begin{array}{l}\text { Revista Contemporánea, } \\
\text { Madrid n }{ }^{\circ} 13 \text { (15-1-1878), p. } 488\end{array}$ & Liberal europeista \\
\hline
\end{tabular}




\begin{tabular}{|c|c|c|}
\hline PADRE CASTRO & $\begin{array}{l}\text { TÍTULO Y DATOS DE LA } \\
\text { PUBLICACIÓN }\end{array}$ & $\begin{array}{l}\text { CARÁCTER DE } \\
\text { LA PUBLICACIÓN }\end{array}$ \\
\hline $\begin{array}{l}\text { Furibundo atleta ultra- } \\
\text { realista }\end{array}$ & $\begin{array}{l}\text { La Ilustración Española y Americana, } \\
\text { Madrid, } \mathrm{n}^{\circ} 27 \text { (22-7-1878) p. } 42\end{array}$ & $\begin{array}{l}\text { Liberal y } \\
\text { monárquico }\end{array}$ \\
\hline Calumniador & $\begin{array}{l}\text { La Autonomía, } \\
\text { Palma de Mallorca, no } 303 \text { (10-7- } \\
\text { 1884), p. } 1\end{array}$ & Republicano \\
\hline Adulador & $\begin{array}{l}\text { La América, } \\
\text { Madrid, n }{ }^{\circ} 19 \text { (13-10-1885), p. } 12\end{array}$ & Liberal Progresista \\
\hline Tradicionalista & $\begin{array}{l}\text { El Siglo Futuro, } \\
\text { Madrid, no } 3.658 \text { (23-5-1887), p. } 1\end{array}$ & Ultracatólico \\
\hline Muy reverendo & $\begin{array}{l}\text { Revista Contemporánea, } \\
\text { Madrid (Octubre de 1891), p. } 81\end{array}$ & Liberal europeista \\
\hline Bramador & $\begin{array}{l}\text { Pluma y Lápiz, } \\
\text { Barcelona, nº } 157 \text { (25-10-1903), p. } 7\end{array}$ & Modernista \\
\hline Iracundo & $\begin{array}{l}\text { Revista Contemporánea, } \\
\text { Madrid no } 128 \text { (15-1-1904), p. } 431\end{array}$ & Liberal europeista \\
\hline Sanguinario & $\begin{array}{l}\text { La Justicia, } \\
\text { Tarragona, no } 486 \text { (5-4-1905), p. } 1\end{array}$ & Republicano \\
\hline Iracundo & $\begin{array}{l}\text { Flores y Abejas, } \\
\text { Guadalajara, no } 580 \text { (15-10-1905), } \\
\text { p. } 4\end{array}$ & Liberal conservador \\
\hline Fray & $\begin{array}{l}\text { La Unión Ilustrada, } \\
\text { Málaga, n } 139 \text { (12-5-1912), p. } 8\end{array}$ & Conservador \\
\hline Fray & $\begin{array}{l}\text { La Ilustración Artística, } \\
\text { Barcelona, no } 1.606 \text { (7-10-1912), p. } \\
654\end{array}$ & Liberal \\
\hline Reaccionario & $\begin{array}{l}\text { Revista de Ciencias Jurídicas y } \\
\text { Sociales, } \\
\text { Madrid, no } 22 \text { (Abril-junio 1923), p. } \\
152\end{array}$ & Krausista \\
\hline Fanático & $\begin{array}{l}\text { La Libertad, } \\
\text { Madrid, n } 2.2 .94 \text { (29-7-1927), p. } 1\end{array}$ & $\begin{array}{l}\text { Liberal y } \\
\text { republicano }\end{array}$ \\
\hline Exaltado y radical & $\begin{array}{l}\text { El Día de Cuenca, } \\
\text { Cuenca, no } 1.975 \text { (6-5-1928), p. } 1\end{array}$ & $\begin{array}{l}\text { Liberal y } \\
\text { monárquico }\end{array}$ \\
\hline $\begin{array}{l}\text { Especie de El Siglo } \\
\text { Futuro }\end{array}$ & $\begin{array}{l}\text { Diario de Alicante, } \\
\text { Alicante, } \mathrm{n}^{\circ} 5.817 \text { (29-3-1930), p. } 1\end{array}$ & Liberal \\
\hline Absolutista & $\begin{array}{l}\text { El Progreso, } \\
\text { Santa Cruz de Tenerife, nº } 7.501 \text { (23- } \\
4-1930), \text { p. } 1\end{array}$ & Republicano \\
\hline
\end{tabular}




\begin{tabular}{|l|l|l|}
\hline \multicolumn{1}{|c|}{ PADRE CASTRO } & \multicolumn{1}{|c|}{$\begin{array}{c}\text { TÍTULO Y DATOS DE LA } \\
\text { PUBLICACIÓN }\end{array}$} & $\begin{array}{c}\text { CARÁCTER DE } \\
\text { LA PUBLICACIÓN }\end{array}$ \\
\hline $\begin{array}{l}\text { Antecesor de Herrera } \\
\text { Oria }\end{array}$ & $\begin{array}{l}\text { Heraldo de Cuenca, } \\
\text { Cuenca, } \mathrm{n}^{\circ} 17(27-5-1935), \mathrm{p} .3\end{array}$ & Republicano \\
\hline Burdo ingenio & $\begin{array}{l}\text { La Libertad, } \\
\text { Madrid, } \mathrm{n}^{\circ} \text { 4.769 (14-7-1935), p. 1 }\end{array}$ & $\begin{array}{l}\text { Liberal y } \\
\text { republicano }\end{array}$ \\
\hline $\begin{array}{l}\text { Monje de San } \\
\text { Jerónimo }\end{array}$ & $\begin{array}{l}\text { La Vanguardia Española, } \\
\text { Barcelona, núm. 23.778 (15-11- } \\
\text { 1942), p. 2 }\end{array}$ & Franquista \\
\hline Batallador & $\begin{array}{l}\text { Falange, } \\
\text { Las Palmas de Gran Canaria, } \mathrm{n}^{\circ} \\
\text { 7.076 (2-5-1953), p. 3 }\end{array}$ & Falangista \\
\hline
\end{tabular}

En los años de edición de Gazeta de la Provincia de La Mancha y Atalaya de La Mancha en Madrid sobresalieron las denominaciones de "flor de los serviles gaceteros", "R. P. manchego", "padre Atalaya, "padre Atalaya de La Mancha", "religiosísimo religioso", "padre gacetero", "padre atalayero" o Ex-gacetero de La Mancha. En los mismos periódicos de Castro o en otros absolutistas -como en El Procurador General de la Nación y del Rey o Exacto Diario en La Coruña-, se utilizaron referencias como padre Atalaya o gacetero con relativa frecuencia. O sea, que algunas que le aplicaban en la prensa liberal de su época fueron apreciadas por él y no le importó su uso, aunque cabe pensar que el sentido era distinto en los periódicos absolutistas que en los liberales. No obstante, ya en 1813 aparecieron calificaciones que trataron de denostar la figura del fraile, como "M. R. P. fray Gerundio de Ciudad Real, "Fr. Gerundio de Ciudad Real", "padre de la risa", "procurador del los serviles", "su paternidad" o "su paternidad Panza", con el doble sentido de Sancho Panza de La Mancha y tripudo. Durante el Trienio Liberal se le dedicaron duros epítetos como fanático, ignorante, injurioso, cerdoso, mugriento, "apóstol del despotismo"..., aunque se siguió utilizando el de "padre Atalaya" o, sencillamente, el de fray.

Los términos empleado desde el Trienio hasta el Franquismo, como puede observarse en el cuadro anterior, son muy diversos, desde bramador, calumniador, exaltado, fanático, furibundo, ignorante, iracundo, radical, reaccionario o sanguinario hasta tradicionalista (de El Siglo Futuro), batallador (de Falange) o sencillamente "monje de San Jerónimo" (de La Vanguardia Española), pasando por otros como absolutista, adulador, célebre... En algunos casos se trataba de presentar al personaje con una referencia comprensible por los lectores del momento, como 
"especie de El siglo Futuro", en 1930, en referencia a Atalaya de La Mancha en Madrid, o "antecesor de Herrera Oria", alma del diario católico El Debate, que se utilizaba en 1935 en el periódico Heraldo de Cuenca, afín al partido Izquierda Republicana, para intentar buscar en el presente personajes similares al padre Castro.

También se pueden recordar con más detenimiento dos ejemplos de la prensa conquense, en los que el padre Castro aparecía como personaje histórico debido a su nacimiento en Tarancón. Se trata de una biografía publicada en El Día de Cuenca y de una leve referencia en un artículo sobre Fernando VII en Heraldo de Cuenca ${ }^{41}$. En la primera se le pinta como fraile y periodista de temperamento exaltado y de ideas altamente radicales, en sentido absolutista, defensor a ultranza de Fernando VII como monarca absoluto y despiadado enemigo de cuanto fuera liberal. La biografía tiene un error importante al afirmarse en ella que huyó cuando empezó la segunda época constitucional y que formó parte de las filas de los "agraviados". Sin embargo, el autor acertaba plenamente al indicar que hubo una línea de continuidad entre el pensamiento del padre Castro, los denominados agraviados y los carlistas. En la segunda, se le presentaba como un buen antecesor de Ángel Herrera Oria, periodista, político y sacerdote fundador del diario católico El Debate, y se indicaba a continuación lo siguiente: "El Escorial, como hoy, dirigiendo la política de España. Ostolaza entraba en el palacio más de lo debido, parecía un embajador del padre Castro en el noticiario palaciego". El autor del artículo, el maestro Emilio Porta Vidal, trataba de poner de manifiesto la intromisión del clero católico en el ámbito político, tanto en la época de primera restauración borbónica con Fernando VII como durante la Segunda República.

\section{El gacetero de La Mancha}

La invasión de los franceses llevó al padre Castro a volver a la provincia de La Mancha y desde Ciudad Real marchó a Madrid en 1813, cuando los franceses salieron de la capital, donde ayudó a extender una determinada idea de La Mancha. Su imagen y la de los manchegos, asociada tradicionalmente de forma esquemática al Quijote y al vino de Valdepeñas, iba a cambiar, además de otros factores, como resultado de la actividad periodística del padre Castro, del "gacetero de La

41 Álvarez M. del Peral, "Conquenses ilustres. Agustín Castro", El Día de Cuenca, núm. 1.975 (6-5-1928), p. 1; y E. Porta Vidal, "Fernado VII, juez”, Heraldo de Cuenca, núm. 17 (27-51935), p. 3. Emilio Porta Vidal fue autor de la obra titulada La Dictadura en las aldeas. Notas e impresiones, Valencia, Imp. Pont, 1930. 
Mancha”, como se le denominó en diversos periódicos de la época. A la imagen tradicional, completada con la idea de pobreza, sequía y desidia, se iba a unir la de territorio conservador, en el mejor de los casos, cuando no el de reaccionario y ultraclerical.

Galdós, en esa línea, daba vida a un personaje absolutista que tenía en la Atalaya su guía espiritual y política. La nostalgia le asaltaba al recordar los días en que se sentían "esclavos de la libertad, suspensos entre la vida y la muerte", y sin saber cuándo verían el fin de la "horrible tiranía de mamones, caparotas, cuácaros, lameplatos y ceposquedos", nombres dados por el padre Castro, según el gran escritor canario, a los liberales ${ }^{42}$. O Blasco Ibáñez, por recordar otra muestra, que marcaba a su personaje, el conde de Baselga, con el carácter de realista decidido, del que se ocupaban periódicos como Atalaya de La Mancha en Madrid, El Regenerador u "otros papeluchos redactados por furibundos frailes" 43 .

Como en otras zonas del país, en 1808 comenzó la propaganda contra los franceses, destacándose de forma retórica la valentía de los manchegos ${ }^{44}$. Pero hasta 1811 no apareció una publicación periódica, en la zona montañosa de Elche de la Sierra, titulada Gazeta de la Junta Superior de La Mancha. Desde el 15 de agosto de 1812, con el número 18, pasó a imprimirse en Alcaraz y finalmente en Ciudad Real, concretamente desde el 17 de octubre de ese año (número 26), donde dejó de publicarse. Dicha gaceta, con noticias diversas pero muy especialmente del conflicto bélico, puede ser considerada como la primera publicación periódica editada en la provincia de Ciudad Real y también en la de Albacete ${ }^{45}$. Apareció semanalmente desde el 13 de abril de 1811 y

42 B. Pérez Galdós, Memoria de un cortesano de 1815, Madrid, Alianza, 1984, pp. 11 a 22.

43 V. Blasco Ibáñez, La araña negra, Barcelona, Seix, 1892-1893, 2 vols.

44 Proclama de la Mancha. Manchegos: el mundo está admirado de vuestras hazañas y valor, S.l., s.i., s.a. El título está tomado de inicio de texto y en el final figura lo siguiente: Dado en nuestro Quartel general ambulante de las riberas de Guadiana á 27 de Junio de 1808. Por mandado del Señor Diego López Membrilla, que no sabe escribir.

45 Hace años se publicaron dos artículos sobre esta publicación: M. Sánchez Picazo, "La Gaceta de la Junta Superior de La Mancha (1811-1812)", en Transformaciones burguesas, cambios políticos y evolución social (l). Tomo IX, Toledo, Junta de Comunidades de Castilla-La Mancha, 1988, pp. 25-31; y R. Carrilero Martínez, "Aproximación histórica a la guerra de la independencia en la provincia de La Mancha según la Gaceta de la Junta Superior (1811-1812)", en Anales del Centro de la UNED, Albacete, núm. 6 (1984), pp. 163-223. En ellos se pueden ver las principales características de la publicación periódica o el análisis de sus contenidos. Y en 1990, en las actas de un congreso celebrado en Madrid el año anterior, se incluyeron otros dos: P. Jurado Sánchez, "La Revolución Francesa a través de la Atalaya de la Mancha de Madrid", en E. de Diego García, J. S. Gutiérrez Álvarez, R. Contreras Miguel, A. Bullón de Mendoza Gómez de Valugera (coords.), Repercusiones de la Revolución Francesa en España [actas del Congreso Internacional celebrado en Madrid, 27-30 noviembre 1989], Madrid, Universidad Complutense, 1990, pp. 701-711; y A. Guijarro Hijas, "Liberales y afrancesados en la Atalaya de la Mancha”, en E. de Diego García, J. S. Gutiérrez Álvarez, R. Contreras Miguel, A. Bullón de Mendoza 
el número 46 salió el 4 de abril de 1812, con numeración continuada que significó un rotal de 537 páginas. El 11 de abril comenzó otra vez con el número 1 y el día 5 de diciembre de 1812, con el número 33 y 396 páginas, acabó su vida. O sea, se publicaron en total 79 números con 933 páginas. Cuando ya se imprimía en Ciudad Real periódicos liberales como El Conciso o Diario Mercantil citaban al padre Castro como el "gacetero manchego" o el "padre gacetero de La Mancha" ${ }^{46}$.

En la Gazeta se puede observar frecuentemente cómo la primera víctima de la guerra es la verdad y cómo lo importante era el insulto al rey José y la loa desmedida al rey Fernando. El primero apareció citado con un buen número de figuras, con las que se trataba de hacer mofa, como "Archi-mosquito", "benéfico Pepe", "José NABO", "mamarracho Pepe", "padre tirano", "rey de farándula”, "rey Pepe”, "rey rapiña", "trashumante magestad", "rey filósofo"..."7. Esta última denominación con sentido peyorativo, evidentemente, y en contra de la idea de Platón de que los filósofos podía ser los mejores gobernantes.

Cuando cesó la edición de la Gazeta de la Junta Superior de La Mancha Castro empezó a publicar la Gazeta de La Mancha o Gazeta de la Provincia de La Mancha, pues con esos dos títulos la he visto citada, obra personal del padre Castro, aunque el título correcto es el segundo ${ }^{48}$. Pero el periódico liberal El Conciso, editado en Cádiz, la citó en variadas ocasiones como Gazeta de la Mancha ${ }^{49}$.

¿Qué había sucedido? ¿Cuál era la razón de la nueva publicación? Pues que a requerimiento del Ayuntamiento de Villanueva de los Infantes las Cortes habían suspendido en sus funciones a la Junta Superior de la Provincia de La Mancha, hecho que se hizo público a finales de 1812. El poder en los ayuntamientos estaba en juego y los absolutistas, con Erro a la cabeza, habían dado una especie de golpe anulando las elecciones municipales celebradas, seguramente porque no les habían

Gómez de Valugera (coords.), Repercusiones de la Revolución Francesa en España [actas del Congreso Internacional celebrado en Madrid, 27-30 noviembre 1989], Madrid, Universidad Complutense, 1990, pp. 691-700.

46 En el Diario Mercantil del día 21 de noviembre se le denominaba así: "P. J. C. se dirije al Padre gacetero de la Mancha formando un paralelo entre él y D. Quixote sobre el poco juicio que manifiesta en sus escritos”. Ver El Conciso, Cádiz, núm. 23 (23-11-1812), p. 8. También, por ejemplo, en El Conciso, Cádiz, núm. 15 (15-11-1812), p. 8.

47 I. Sánchez Sánchez, "La guerra de los papeles en Castilla-La Mancha (1808-1815)", en F. Asensio Rubio y Á. R. del Valle Calzado: Actas de las Jornadas Guerra de la Independencia: Valdepeñas en la España del siglo XIX. Ciudad Real, Ayuntamiento de Valdepeñas y Centro Asociado UNED Valdepeñas, 2010, pp. 99-148.

48 Ver C. González Echegaray, Periódicos y revistas de la Guerra de la Independencia y reinado de Fernando VII en la Hemeroteca Nacional, Madrid, Hemeroteca Nacional, 1981, pp. 55.56. En la Hemeroteca Nacional se conservan los números 1 (2-1-1813) a 14 (15-5-1813), que se tiraron en la Imprenta de la provincia, ya ubicada en Ciudad Real.

49 Es el caso de El Conciso, núm. 11 (11-2.1813), pp. 1-2. 
sido propicias. Por eso, el padre Castro, amigo del citado Juan Bautista Erro, empezó la edición con un título en el que no figuraba, como anteriormente, la Junta Superior, para intentar la defensa de las actuaciones desarrolladas en la mencionada Junta ${ }^{50}$.

La prensa liberal acogió a la nueva publicación con fuertes críticas. El Conciso, por ejemplo, fustigaba en un largo artículo a Agustín de Castro y a su Gaceta de la Provincia de la Mancha. En primer lugar hay que recordar las formas con la que se dirigían al director: "M. R. P. Fr. Gerundio de Ciudad-Real", "V. y los demás tunantes de su ralea", "V. y en los demás de su cuadrilla", "frai Gerundio" o "fecundisimo Redactor". Además, se llegaba a denominar a sus escritos como "petulantísimas gerundiadas de su gazeta" 51 .

Empezaba el artículo con la acusación a Castro de cometer diversos abusos, se afirmaba a continuación que eso debía terminar y se insertaba un duro texto dividido, además de una introducción y la correspondiente conclusión, en cuatro líneas argumentales. En la introducción se planteaba que los artículos de Castro, llamados "descomunales gañidos con que atruena la Mancha”, no llegaban a impresionar a las buenas gentes. Estas, se escribía, no volverían a poner en el padre Castro y "en los demás de su cuadrilla" dinero y confianza pues la mayoría ya estaba desengañada y de acuerdo con los liberales, pintados por Castro como "hereges y libertinos". El pueblo y los liberales querían "orden, mejoramiento, restitución de las cosas á los buenos principios constitutivos de cada ramo" y los frailes estaban bien si eran lo que debían ser, pero muy mal si eran lo que el padre pretendía que fueran.

Con el desarrollo del primer argumento se pedía a los frailes que estuviesen en clausura y recogimiento, lejos de los afanes del siglo, "sin salir á ese mundo á gobernar las casas y á inquietar las familias”. En los conventos debían rogar a Dios por los demás y darles ejemplo de penitencia, abstracción y retiro. Se terminaba, como en las otras líneas argumentales, con la frase siguiente: "O verdaderos frailes ó nada". A continuación, con el segundo, se acusaba a los frailes de dejar entrar en los conventos a mujeres: "sabe V. mui bien, frai Gerundio, que esos grandes desórdenes han cundido, y existen por el presente aun con más desenfreno que en los tiempos pasados". Ni los liberales, ni en pueblo quieren que los frailes tengan mujeres, se decía, y eso es lo que los primeros querían remediar.

El tercer argumento servía para afirmar que liberales y pueblo querían que los frailes se contentasen con lo necesario, con las haciendas

50 Ver Gazeta de la Provincia de La Mancha, Ciudad Real, núm. 1 (2-1-1813), pp. 3-12.

51 El amigo de la razón, ni liberal ni servil, "Tapaboca al redactor de la Gazeta de La Mancha”, en El Conciso, núm. 5 (5-3-1813), pp. 1 a 5. 
precisas para vivir con sobriedad y que no estuvieran a la "caza de legados, de mandas ni de limosnas, que quitan ó amenguan su patrimonio a los pobres paisanos, para añadirse Vds. superfluidades, y atesorar riquezas, que les son tan dañosas, como oportunas y necesarias á los que las circulan y aumentan con su trabajo, y concurren con ellas a mantener el Estado". Y en la cuarta se deseaba que los frailes estuvieran en su clausura, no en el mundo "tras las picaruelas hijas del viejo Adán", trabajando y conjurando el ocio. Con ello evitarían en gran medida la petición de tanta limosna y tanta ayuda.

El redactor recordaba en las cuatro lineas, en sintonía con planteamientos sociales y económicos del liberalismo, textos de la Iglesia en los que se defendían las ideas expresadas y la conclusión era muy fuerte: "Recorte V. bien estos textos que se los he vertido en castellano por si no entiende bien el latín, rumielos V. hasta otro correo, y rebiente si quiere con este pienso, hasta otro que esté de humor y le vuelva a llenar el pesebre". Evidentemente, la contestación de Agustín de Castro no se hizo esperar, pues aparte de lo escrito en su Gazeta, publicó incluso un folleto, reimpreso en varios lugares ${ }^{52}$, que reflejó también en el número prospecto de Atalaya de La Mancha en Madrid y que analizaré más adelante.

El 17 de mayo de 1813 publicaba El Conciso un breve y contundente texto fechado en Ciudad Real el 7 de mayo, dirigido a Castro pero sin nombrarlo directamente: "Ya lleva el erario nacional desembolsados más de 609 reales en sostener la Gaceta de la Mancha, obra de un P. Gerónimo, y papel que solo sirve para amortiguar el espíritu público, esparcir la semilla de la discordia, conservar al pueblo en la ignorancia, desconceptuar al soberano Congreso, e introducir la desconfianza para con el actual gobierno. Es mui estraño que el Intendente apruebe semejantes cuentas gacetiles, y que el producto de este periódico no entre en Caxa, y debería reintegrar estos gastos el Sr. consentiente Intendente: es también mui extraño que haya juntas provinciales que den ó consientan esta comisión á sujetos, de quienes debe creerse no pueden aprobar ninguna reforma que sea contra su panza y holganza" ${ }^{33}$. La repercusión del texto llegó a ser fulminante pues el día 15 de mayo apareció el último número de la Gazeta de la Provincia de La Mancha.

El padre Agustín de Castro se había convertido desde La Mancha en un referente nacional del absolutismo y de su prensa antes de marchar a Madrid para levantar allí su Atalaya de papel. Por ejemplo, el servil Diario de la Tarde de 3 de diciembre de 1812 reproducía un artículo suyo

52 Ver, por ejemplo, El Redactor de la Gazeta de la Mancha, Al autor del tapaboca publicado en el Redactor General del 4 de marzo. El redactor de la Gazeta de la Mancha, Sevilla, Imp. de los Herederos de Padrino, 1813 (Reimpresión).

53 El Conciso, Cádiz, núm. 17 (17-5-1813), p. 7. 
que merecía al redactor de El Conciso el siguiente comentario: "Artículo de la gaceta del R. P. Manchego, relativo á la quema de francmasones. La fogueada fantasía del Reverendo presenta el plan infernal de una fiesta de caníbales (propia invención de un familiar), manifestando su pia intención de degollar, quemar, atormentar..." 54.

\section{4. "Y NOSOTROS CON ELLOS JURAMOS SU OBSERVANCIA"}

Con esta frase terminaba su exortación el padre Castro en la misa de jura de la Constitución, que tuvo lugar en Villanueva de los Infantes el día 26 de julio de 1812. El fraile se refería a los ilustres representantes de la provincia de La Mancha (Los Erros, los Canedos, los Ortices, los Garcías y Toribios) y él juraba junto a ellos el Código constitucional ${ }^{55}$. Pero empezaba con otra que, conociendo la evolución posterior del fraile, llama poderosamente la atención: “Acabais de oir, Señores, la voz magestuosa de la Gran Nación española que desde el sabio congreso de las Cortes generales nos presenta este libro inmortal en que fixa la suerte de nuestros destinos y la gloria de nuestra posteridad".

Intensificaba después el padre Castro la apología del texto constitucional afirmando que se acababa gracias a él la esclavitud doméstica, cesaba la arbitrariedad, se recobraba el imperio de la ley y el español entraba en la posesión de la libertad civil, "desgraciadamente olvidada por la larga costumbre de arrastrar cadenas". No obstante, tras las alabanzas citadas, y otras que expresó, es preciso recordar que el orador, aparte de utilizar conceptos como los de libertad, ciudadano o Nación, sólo destacaba cuatro cuestiones del texto constitucional: España no tenía otra religión que la "católica, apostólica, romana, única verdadera" y, además, se imposibilitaba el ejercicio de cualquier otra; Fernando era el rey, lo que aseguraba la continuidad de la monarquía; la nación era libre y no podía ser patrimonio de ninguna familia ni persona; y se aprobaba la libertad individual, que la Nación se obligaba a proteger, junto a la propiedad y los derechos. Y decía más, el padre Castro, aunque no sabemos qué presión ambiental tuvo el escribir su discurso, pero por su evolución posterior sabemos que eran palabras hueras. Ya no había que temer el ascendiente de los reyes, ni la violencia del ministro, ni la prevaricación del magistrado, ni la invasión del convecino: "delante de mi todas las fuerzas son iguales”.

54 El Conciso, Cádiz, núm. 6 (6-12-1812), p. 8.

55 A. de Castro, Oración que en la misa solemne de la jura de la Constitución política de la nación española dixo a la Junta Superior y pueblo de Infantes el redactor de la Gazeta de La Mancha, Elche de la Sierra, 1812. Apareció junto al número 16, del sábado 1 de agosto de 1812, de la Gazeta de la Junta Superior de La Mancha. 
Sin embargo, la Constitución de 1812 fue aceptada de forma coyuntural por sectores que relativamente pronto se alinearían en las filas del anticonstitucionalismo y el absolutismo, como ocurrió con el padre Castro. Y es que el texto constitucional, según las ideas expresadas reiteradamente por los autores reaccionarios, era hijo de la Revolución francesa y esta no significaba otra cosa que "la irreligión, el asesinato, el robo, la mala fe, el libertinage, la mentira, el engaño, el despotismo bajo la capa de libertad" 56 . Y toda la oposición formada en su contra generó una línea de pensamiento presente en España durante la época contemporánea, que veía en los principios revolucionarios y en el liberalismo un serio peligro.

Durante el Franquismo, punto culminante de ese pensamiento reaccionario, impuesto además por la fuerza y la propaganda machacona, la síntesis sobre la cuestión, según historiadores u otros autores, se podría expresar en pocas palabras. Un grupo de ilustrados quiso sepultar en el olvido el viejo y tradicional espíritu de España y transformarla en una nación "moderna" y "libre", lo que para sus componentes era instalar una imitación de la Francia revolucionaria. La oportunidad llegó, según esa visión, con la Constitución de 1812 y, aunque los liberales tuvieron que ceder en algunas cuestiones, como en los temas del catolicismo o la monarquía, en realidad se aprobaron cosas más prácticas para sus intereses, como el fin de la Inquisición o la libertad de imprenta, por ejemplo. Esa ha sido la dicotomía, lo genuinamente español, la tradición, frente a lo extranjero, a lo que llegaba de fuera. E importantes sectores de la Iglesia católica, además del nacionalismo español radical y excluyente -lo que Vicente Palacio Atard denominaba "derecha española histórica"-, estuvieron en la vanguardia de ese pensamiento durante el siglo XIX y gran parte del XX.

Por ejemplo, el diario católico El Debate, a través de su línea editorial, puede ser una buena muestra. En 1934 se citaban los "moldes extraños para una obra nacional" y reclamaba el tránsito por caminos nacionales, pues fuera de España, según el editorialista, ya se habían pasado dos siglos que, evidentemente, para ese pensamiento habían sido centurias perdidas al intentar hacerse con moldes extraños la construcción nacional ${ }^{57}$. En ese sentido, la Constitución de 1812, en reflexión expuesta en su primer centenario, no era una gloria para la mayoría de los españoles, "sino una vergüenza nacional", mientras que las Cortes de Cádiz habían sido "funestísimas, verdadero borrón en la historia de

56 Atalaya de La Mancha en Madrid, núm. 16 (3-9-1813), p. 124.

57 El Debate (20-1-1934). Estos textos editoriales en J. M ${ }^{a}$ García Escudero, El pensamiento de «El Debate». Un diario católico en la crisis de España (1911-1936), Madrid, Biblioteca de Autores Cristianos, 1983. 
nuestra patria" ${ }^{58}$. Además, aquella Asamblea no fue de legítima representación nacional y no representó, por tanto, el sentimiento verdaderamente español, "hostil, entonces como ahora a un sistema que no puede ni podrá jamás tener firme arraigo en nuestro país" 59 .

Pero la falta de arraigo no era debido seguramente a carencias de los españoles o a la copia de modelos foráneos sino, precisamente, a la omnipresencia de fenómenos como el clericalismo y el caciquismo, que impedían la consolidación. En esa línea, unos años antes, el médico, político y criminólogo Rafael Salillas y Panzano publicó en Madrid la obra El delincuente español, en la que presentaba, según su criterio, las características de la sociedad española del momento, de finales del siglo $\mathrm{XIX}^{60}$. Escribía que, efectivamente, en España existía una gran dificultad para implantar el constitucionalismo y afirmaba que la Constitución no formaba parte de la envoltura orgánica del pueblo español, ni siquiera era su piel, pues era un elemento no encarnado. En realidad, afirmaba, sólo se trataba de una vestimenta acomodaticia.

Salillas ponía de manifiesto a finales del XIX que todos los alardes y envanecimientos políticos por las libertades constitucionales, sólo conquistadas por el empuje persistente de hasta tres generaciones políticas, se desvanecían con una sola apelación, manifestada por la conciencia nacional desilusionada: el caciquismo. La entonces relativamente nueva vestimenta constitucional, decía, oscurecía ante el poder de los caciques y creaba un dualismo generador de antinomias, una intensa diferencia entre legalidad y realidad, tan frecuente en nuestra Historia contemporánea: "En España existe el sufragio universal=En España no existe la libertad electoral. En España existe una organización judicial aparentemente bien establecida=En España no existe la independencia del poder judicial. España es una Monarquía constitucional (y lo mismo fuera decir una República, cuando existió)=España es una federación oligárquica”.

Para el pensamiento reaccionario, ultracatólico y ultraconservador el siglo XIX fue la centuria anticristiana por excelencia. Por ejemplo, en una revista mensual de los jesuitas, con importante tirada ${ }^{61}$, se presentaba al XIX con una mala infancia ya que tuvo como "nodriza a la revolución y la revolución fue anticristiana". Fue así pues se arrojó de su altar a Cristo para poner en su lugar los derechos del hombre, escribía el autor jesuita, y se "tuvo la avilantez de colocar en el trono que ocupaba la Madre de Dios, ideal de toda pureza, á una descocada meretriz arran-

58 El Debate (8-3-1912).

59 El Debate (6-10-1912).

60 R. Salillas, Hampa (Antropología picaresca), Madrid, Librería de Victoriano Suárez, 1898, p. 371.

61 J. A. Zugasti, "Fin de siglo", El Mensajero del Corazón de Jesús y del Apostolado de la Oración, Bilbao (Diciembre de 1900), pp. 515-521. 
cada de los lupanares de París, que no tenía nada de ideal por más que la llamaran la razón, ni de sobrehumana, por más que la proclamaran diosa". Y seguía el análisis de la centuria con parecidos argumentos para la adolescencia, virilidad o postrimerías, figuras usadas por el clérigo para describir el siglo XIX. O sea, para algunos sectores eclesiásticos tanto la libertad, como los derechos del hombre o la razón fueron los grandes enemigos a los que persistentemente había que combatir. Por eso no es raro ver en épocas de libertad, como el Sexenio Revolucionario, imágenes como la aparecida en el periódico El Anti-Cristo, en la que unos clérigos armados con crucifijos y tras una cañón disparaban a una figura que representaba la libertad y aparecía el siguiente diálogo: “- Valientes, con estas armas la victoria es nuestra... ¡Fuego! // - ¡Estúpidos!”62.

\section{Atalaya en Madrid contra la Constitución y el liBeralismo}

José María Queipo de Llano Ruiz de Saravia, conde de Toreno, calificaba en 1820, en el exilio parisino, como hojas inmundas y violentas al periódico del padre Castro ${ }^{63}$. Es sólo una muestra de la consideración que merecía en general a los políticos liberales el instrumento absolutista del monje Jerónimo. Un escritor, Ramón de Mesonero Romanos, recordaba también la publicación del padre gacetero en sus Memorias de un setentón de forma muy crítica: "La Atalaya de la Mancha, furibundo atleta ultra-realista, en que esgrimía sus armas el padre Castro, monje de San Jerónimo" ${ }^{64}$. Y es que el clérigo amparó todo tipo de barbaridades en su publicación. Se puede recordar, por ejemplo, lo que pudo leerse en el número de 29 de mayo de 1814, cuando Fernando VII ya había vuelto:

“Cómo es que no se ven ya todas las plazas de las capitales cubiertas de suplicios? ¿Cómo es que no se han quemado ya vivos un centenar de impíos, cuyos horrendos crímenes contra la Religión y el Trono están sellados en sus mismos diarios de Cortes y en sus periódicos? $¿$ Como es que tanto afrancesado como insultaba nuestra lealtad disfrutando los empleos que debían haber servido de premio á la fidelidad y al patriotismo, viven todavía entre nosotros, y en pacífica

62 El Anti-Cristo, Madrid, sermón 1 (26-11-1868). Reproducido en Valeriano Bozal, La ilustración gráfica del siglo XIX en España, Madrid, Comunicación, 1979, p. 126.

63 Conde de Toreno, Aperçu des révolutions survenues dans le gouvernement d'Espagne, depuis le premier moment de l'insurrection, en 1808, jusqu'à la dissolution des Cortès ordinaires en 1814. Traduit sur l'original écrit par un Espagnol à Paris, París, Corréard, 1820.

64 R. de Mesonero Romanos, Memorias de un setentón, natural y vecino de Madrid, Madrid, Ilustración Española y Americana, 1880, p. 107. 
posesión de sus destinos? Tales son los gritos que el deseo de la seguridad del trono de nuestro Soberano arranca estos días a infinitos de los que le aman, al ver la audacia con que no temen explicarse todavía sus encarnizados enemigos. Pero suspended un poco vuestros justos sentimientos, ó buenos españoles. Es cierto, sí, que las grandes convulsiones reclaman prontos y exemplares castigos, porque tanto su dilación como su benignidad aumentan tan extraordinariamente el atrevimiento de unos malvados que han jurado no dar un paso retrógrado jamás : pero delitos tan complicados y de tanta trascendencia como los de nuestros enemigos, exigen la indagación de todos los principales reos, que si quedaran vivos entre nosotros, podrían perdernos todavía; y esta tan interesante indagación requiere tiempo, por mucho que se active" 65 .

Y el escrito terminaba con esta sentenciosa frase: "Dad tiempo al tiempo, y vosotros veréis todo quanto desea vuestro corazón". Y los españoles lo vieron, claro que lo vieron. Contemplaron una gran represión acompañada de quemas de constituciones, hogueras de libros, regreso de la Inquisición, ostracismos, crímenes, encarcelamientos, vuelta al absolutismo y extensión de frases que se lucían en las escarapelas y otros soportes como aquella de "Viva Fernando Séptimo, la Patria y la Religión, y muera la Constitución".

Pero hay que recordar el inicio de la publicación del padre Castro, donde planteaba sus objetivos y su plan editorial ${ }^{66}$. En el número prospecto comenzaba diciendo que tras la prohibición para editar su publicación periódica en La Mancha se había trasladado a Madrid, aunque los liberales no debían cantar victoria. Escribía que en su publicación los manchegos habían visto copiadas al vivo sus opiniones, se esponjaban en ellas al mismo tiempo que se indignaban con las de los liberales. Por eso, indicaba, al conocerse la suspensión unos en persona y otros por carta le ofrecieron todo tipo de ayudas para no abandonar la provincia. Esa ha sido una de las características de los sectores absolutistas y conservadores, la de hacerse por cuenta propia representantes de la opinión del pueblo. Por otra parte decía que los liberales debían cambiar de táctica y ser más inteligentes pues no bastaba con llamarle "castellano viejo, Fr. Gerundio, D. Quijote, tunante, buey, borrico, vagabundo" o con escribir que un partidario le regaló una yegua, que en las retiradas le daban preferente alojamiento o que le suministraban trigo, arroz, etcétera, etcétera. Debían aprender de "aquellos perillanes traspirenaicos que les sirven de patrón”, pues aunque falsificaban o calumniaban daban un

65 Atalaya de La Mancha en Madrid, núm. 58 (29-5-1814), pp. 471-473.

66 Prospecto al nuevo periódico Atalaya de La Mancha en Madrid (4-7-1813). 
cierto colorido que hacía su efecto en el vulgo. Pero los liberales españoles no podían deslumbrar "sino á algún atolondrado; porque contentos con copiar sus ideas, han creído que no necesitan del estudio y talento que ellos tuvieron para darlas importancia”. Además, "la gente va abriendo el ojo, y rehusa las papillas que queman el hocico".

Su plan editorial estaba inspirado en el amor a la religión, en la "verdadera" libertad y en el deseado Fernando. Situado en la Atalaya iba a contar las cosas que escapasen a su vista, iba a alabar lo bueno, no disimular lo malo y descorrer el velo para conocimiento de los incautos y "si alguno se picase, que se rasque; para eso se nos dieron cinco uñas en cada mano".

Ójala, escribía el fraile, hubiese aprendido algún oficio en la juventud, aunque fuese el de albardero y hoy todo sería mejor que dedicándose a las tareas literarias. Pero "ya está el alcacer duro para zampoñas", es decir, ya no estaba en edad de aprender o hacer algo nuevo. Así que se ponía el ropaje de periodista, "profesión semejante á la del aguador que se aprende al primer viage". Tras la poca consideración hacia el periodismo seguía así: "Saco al mercado mi género prometiendo el oro y el moro: si después no lleno el prospecto, llenaré la bolsa (que es la ilustración y patriotismo), y trampa adelante". En fin, los amantes del orden, los adictos al espíritu de la religión católica, los partidarios de la "libertad razonable" se consolarán. Por tanto, concluía, mal año para el libertino, para el afrancesado, para el que siembra la discordia, para el que abusa del poder y para el que se afana en socavar los cimientos de la libertad cristiana.

Su llegada a Madrid desde Ciudad Real no había pasado inadvertida para la prensa liberal, que la registraba y aprovechaba para criticar al fraile. No se puede saber la veracidad, pues no he podido contrastar con otra fuente, pero El Conciso se hacía eco de la estancia en la capital del padre Castro y el redactor escribía que el 4 de agosto de 1813, a la una y veinte de la tarde en la Puerta del Sol, cuando volvía del baño "montado en su soberbio y magnífico caballo andaluz", fue silbado desde Correos hasta que entró en la calle Carretas y le gritaron que era mejor que entregara el caballo al ejército. Y se concluía la noticia del siguiente modo: "Este recado y juntamente los silbidos no interrumpidos, incomodaron en extremo a su paternidad Panza, sin embargo con la desfachatez que le es tan peculiar, y de que tiene dadas tan reiteradas pruebas, apretó el paso haciendo ademanes con la cabeza, como indicando que había de anatemizar á todos los concurrentes á la Puerta del Sol, que le habian observado con aquella demostración á que tantos motivos se ha hecho acreedor" 67 . José Bonaparte abandonó Madrid el 17 de marzo de 1813, aunque los

“Artículo semi de oficio”, El Conciso, Cádiz, núm. 16 (16-8-1813), pp. 2-3. 
franceses salieron de la capital dos meses más tarde ${ }^{68}$, y la noticia citada de El Conciso hacía referencia al 4 de agosto, justo un mes después de la publicación del número prospecto de Atalaya de La Mancha en Madrid.

Desde luego los escritos del padre Castro "no brillaban por el espíritu de caridad, ni de lenidad evangélica", según expresaba el catedrático de Historia Eclesiástica Vicente de la Fuente ${ }^{69}$. Se podrían recordar muchos ejemplos de la aversión a los liberales y de sus contantes ataques al liberalismo y a la Constitución. El número de 19 de octubre de 1813, por ejemplo, incluía una letrilla en la que se citaban las verdaderas características de los serviles ${ }^{70}$. Por supuesto, entre ellas estaban el amor y la sumisión al rey, la huida de rebeliones y del choque de opiniones o el evitar el abuso de la imprenta y la falsa ilustración. Respecto al liberal, el servil debía descubrir sus falsedades, su egoísmo o seducción y detestar tanto al "francesismo" como al liberalismo, que introducía la división.

En la edición de 7 de abril de 1814 se trataba el tema de los diezmos y se citaban de forma peyorativa a "Moros y judíos", que eran tratados como sectas. El liberalismo era una secta, como el jacobinismo, y reunían lo más malo y lo peor de aquellas ${ }^{71}$. Y en el número de un mes después, con Fernando ya en Valencia, se publican unas "Expresiones afectuosas de un español amante de su Rey y de su Patria" y allí se volvían a repetir las descalificaciones de los liberales: "Guardaos FERNANDO, // Del liberalismo, // Que es decir, de ateos // Necios presumidos, // Vanos charlatanes, // Audaces é impíos, // Que se han colocado // En varios destinos"72. Es decir, ateos, tontos, necios y aprovechados.

Casi una obsesión en el periódico fue el tema de la hoguera, como elemento purificador y de castigo. Por ejemplo, en un escrito sobre gaceteros y publicistas, acusados de irreligiosos, se les avisaba del restablecimiento de la Inquisición y entonces todos tomarían el montante para Francia "pues ya hace años que unos, según ellos dicen, olian á chamusquina, y otros han hecho méritos para que se encienda la hoguera"73. Unas semanas después se asustaba a los liberales recordando una gran hoguera en Calahorra a cuyas llamas "dieron pábulo Abejas, Universales, Redactores, etcétera”, todos ellos periódicos liberales ${ }^{74}$.

68 Gazeta de Madrid, núm. 77 (18-3-1813), p. 308. En una breve nota se decía lo siguiente: "El REI nuestro señor salió ayer de esta corte á recorrer las líneas de los exércitos".

69 V. de la Fuente, Historia de las sociedades secretas antiguas y modernas en España, y especialmente de la Franc-Masonería, Lugo, Imp. de Soto Freire Editor, 1870, tomo I, p. 182.

70 "Reglas para conocer á los verdaderos hombres de bien, llamados Serviles por los orgullosos Liberales. Letrilla”, Atalaya de La Mancha en Madrid, núm. 29 (19-10-1813), pp. 230-232.

71 Atalaya de La Mancha en Madrid, núm. 6 (7-4-1814), p. 46.

72 "Expresiones afectuosas de un español amante de su Rey y de su Patria", Atalaya de La Mancha en Madrid, núm. 36 (7-5-1814), p. 293.

73 Atalaya de La Mancha en Madrid, núm. 3 (4-4-1814), p. 19.

74 Atalaya de La Mancha en Madrid, núm. 39 (10-5-1814), p. 317. 
Y en mayo la Atalaya presentaba en sus páginas el torrente de las llamas reaccionarias y represoras. En Burgos, por ejemplo, se describía la alegría en la ciudad, "cubierta de luto hacia ya seis años". El pueblo y la tropa arrancaron la placa que ponía Plaza de la Constitución y se hizo una hoguera, a la que fueron arrojados ejemplares de la Constitución y otros papeles de los liberales. Todo ello en medio de una general aclamación, según se escribía, acompañada de vivas al rey y mueras a la Constitución, lágrimas de alegría y voces que pedían la muerte de los traidores. Después se llevaron las cenizas a casa del Juez político, comenzó la detención de liberales, cuya lista era reproducida en la Atalaya de La Mancha en Madrid, y como punto culminante se sacó en público el estancarte de la Santa Inquisición entre vítores y aplausos. Además, "las confiterías, las tiendas de vinos generosos y demás puestos públicos se franquearon por sus dueños para la tropa y para toda clase de personas: clérigos, soldados, viejos, viejas y mozas baylaban mezclados unos con otros en medio de la plaza, y se abrazaban con la ternura que pudiera manifestar un amoroso padre al rescatar su hijo cautivo, después de muchos años de suspirar por él"75.

Similares "festejos" fueron descritos, por ejemplo, para Cifuentes (Guadalajara), donde entre repique de campanas, luminarias y fuegos artificiales fue quemada la abolida Constitución en una hoguera de la plaza ${ }^{76}$; Algecilla (Guadalajara), población en la que hubo festejos varios, vivas y mueras, quemada a "escopetazos un fantasma imagen de Napoleón", la Constitución arcabuceada, quemada, maldecida y pisada, igual que el decreto de abolición de la Inquisición y otras normas de las Cortes ${ }^{77}$; Colmenar de Oreja (Madrid), donde la "Constitución y demás infames y seductores impresos fueron arrastrados, pateados y reducidos á cenizas, las que fueron arrojadas, y esparcidas al viento para que ni aun esto quedase"78; Palma de Mallorca, ciudad en la que el 26 de mayo se hizo una gran pira y en ella ardieron más de cinco mil ejemplares del catecismo de la Constitución, acabado de imprimir el día anterior para repartirse por los pueblos ${ }^{79}$; Forua (Vizcaya), pueblo en el que tras la función religiosa, se formó una gran hoguera, a cuyo alrededor, incluso los que no sabían castellano, gritaban sin cesar, viva nuestro Rey, viva la Religión, viva la Inquisición y mueran los traidores, tanto que a las nueve de la mañana todavía resonaban los vivas por las calles y los ecos de iluminación poco habitual, cañones, novillos, fuegos de arti-

75 Atalaya de La Mancha en Madrid, núm. 47 (18-5-1814), pp. 388-389; y núm. 52 (23-51814), p. 427.

76 Atalaya de La Mancha en Madrid, núm. 74 (14-6-1814), p. 611.

77 Atalaya de La Mancha en Madrid, núm. 76 (16-6-1814), pp. 627 a 629.

78 Atalaya de La Mancha en Madrid, núm. 90 (30-6-1814), p. 739.

79 Atalaya de La Mancha en Madrid, núm. 93 (3-7-1814), p. 765. 
ficio... Todo ello, se advertía, pagado por la Iglesia: "La función ha sido costeada toda por los Eclesiásticos" $"$; o Fuentespina (Burgos), pueblo en el que sólo había seis Constituciones, que se quemaron y arcabucearon el 31 de mayo, al tiempo que se escuchaba la voz "de un vecino gran español, y decia: Señores, esta Constitución se quema por ser traidora á Dios, al Rey, y á la honra y seso de los Castellanos, y se arcabucea por ser capa de picaros" $"$.

En fin, son sólo unas muestras del terrible mayo que se extendió por toda España para una parte de sus habitantes, aunque para otra todo fueron festejos y alegrías, con las detenciones de liberales, las quemas en hogueras de todo tipo de documentos, los militares y eclesiásticos amparando los excesos reaccionarios, la retirada de las placas con el nombre de la Constitución en calles y plazas, la vuelta de los estandartes de la Inquisición, los gritos a favor de Fernando y la Inquisición, las voces contrarias a la Constitución y los liberales... Todo ello justificado por los daños que se achacaban a liberales, afrancesados, Napoleón y, en última instancia, a la Revolución francesa, madre de la "irreligión, el asesinato, el robo, la mala fe, el libertinage, la mentira, el engaño, el despotismo bajo la capa de libertad, reduciendo á la mas dura esclavitud particularmente al joven que forzadamente se alista bajo de sus banderas, y erigiéndose en legislador universal para tratar al hombre civil á la manera del militar" $" 2$.

\section{Las Cortes y Castro}

El Trienio Constitucional (1820-1823) llegó a su fin debido a la acción del ejército, extranjero en este caso, y el Sexenio Revolucionario (1868-1874) o la Segunda República (1931-1936) terminaron por la intervención de militares españoles golpistas y liberticidas. Parece ser la constante en nuestras historia contemporánea, pues los tres períodos verdaderamente democráticos, con las diferencias que se quieran, terminaron por la intervención de los militares, con el aplauso y el apoyo decidido de la Iglesia en todos los casos. Una Iglesia que lanzó a sus clérigos en 1814 a una lucha contra el liberalismo, que se mantuvo durante todo el siglo XIX. Aunque más avanzado el siglo se pondría en cuestión a la propia religión, durante los agitados años que antecedieron al golpe de 1814, protagonizado por militares, eclesiásticos y Rey, sólo se criticó a la Iglesia; mejor, a una parte de la Iglesia, retrógrada, recalcitrante y reaccionaria. Si en 1814 se encarceló a un buen número

80 Atalaya de La Mancha en Madrid, núm. 95 (5-7-1814), pp. 781-782.

81 Atalaya de La Mancha en Madrid, núm. 146 (30-8-1814), p. 1.181.

82 Atalaya de La Mancha en Madrid, núm. 16 (3-9-1813), p. 124. 
de liberales, la experiencia liberal que empezó en 1820 terminó a fines de septiembre de 1823, el día 27, cuando las Cortes se disolvían, el rey felón era "libre" otra vez, según explicaban los periodistas absolutistas, y Riego, prisionero, entraba en Madrid. La represión contra los liberales volvía a activarse y el periódico absolutista El Restaurador, dirigido por el fraile Manuel Martínez, que había sido redactor de Atalaya de La Mancha en Madrid y después obispo de Málaga, dibujaba así al militar liberal con muy poco espíritu caritativo y un buen cargamento de sangre y exterminio ${ }^{83}$ :
"Entra en Madrid, caudillo de bergantes, Entra ladrón, cobarde y asesino, Emperador presunto de tunantes, Gefe de locos, de impiedad padrino: Entra con confusión de tus amantes Cual traidor Catilina; y tu destino, Tus horrores, oprobio y tu tormento Sírvanles para siempre de escarmiento"

Los horrores que tuvo que pasar el general Riego, símbolo del Trienio, antes de su muerte fueron considerables. Arrastrado en un serón para escarnio público, desde la cárcel hasta la Plaza de la Cebada de Madrid, fue vilipendiado, ahorcado y decapitado, por ese orden. Y la imagen del periódico capitaneado por el que fue obispo de Málaga, en pago a sus desvelos absolutistas, es una buena muestra de la postura de una parte importante de la Iglesia católica.

Sin embargo, los liberales fueron más prudentes y caritativos en 1820, con la implantación del liberalismo, al menos con el padre Castro. En las Cortes, concretamente en sesión pública de 2 de septiembre de 1820, se discutió una indicación de Manuel Quintana que recordaba la actuación de fray Agustín de Castro en su Atalaya, cuando acusó a los liberales de tener preparada otra constitución secreta republicana, que dio impresa párrafo por párrafo y artículo por artículo. La petición concreta de Quintana a las Cortes era la siguiente: "Que para desagravio del decoro nacional, altamente ofendido con esta negra imputación, digan al gobierno, que al referido padre fray Agustín de Castro se le exija inmediatamente el original ó la copia de la dicha constitución, que llama secreta, impresa en estos números, y asimismo una razón puntual de la persona que se la proporcionó,

83 MRC, El Restaurador, Madrid, núm. 85 (1-10-1823), p. 778. 
dando cuenta a las Cortes del resultado de esta diligencia" ${ }^{4}$. Pero tal indicación no fue admitida, según el acta consultada, y no se indagó nada en esa dirección.

La prensa proporcionaba alguna noticia más. Uno de los intervinientes, el conde de Toreno, dijo que si se pidiese tal cosa al padre Castro habría que empezar por los que persiguieron a los diputados, los condenaron y formaron las bases de persecución tan terrible y tan nueva. Añadió que tal cuestión era subalterna y que el "Congreso debía calcular si convendría revolver tanto cuanto se necesitaba para examinar todo lo que se ha hecho en estos seis últimos años" ${ }^{85}$. Quintana contestó diciendo que no sabía a qué artículo de la Constitución se oponía la indicación presentada, a lo que el conde dijo que ni las Cortes ni el Rey podían ejercer cuestiones judiciales y lo que se pedía era un acto judicial. Quintana manifestó entonces que su objetivo era sólo que la nación supiese que no había ninguna constitución secreta, en contra de lo publicado en la Atalaya de La Mancha en Madrid.

Lo cierto es que la publicación de la constitución "secreta republicana", con las graves acusaciones que acompañaban, fue un elemento poderoso para justificar la represión contra los liberales. El padre Castro no hizo nada más que echar leña al fuego con sus diatribas. El sacerdote Joaquín Lorenzo Villanueva, uno de los presos, publicó una obra en 1820 que había escrito en la cárcel ${ }^{86}$. En ella describe todo el proceso y dedica varios capítulos al padre Castro y a su Atalaya, con la descripción de su actuación y sus escritos. Y en uno de ellos trataba la contradicción ya apuntada de un padre Castro cantor de la Constitución en Villanueva de los Infantes y otro detractor de ella en Madrid, es decir, de predicador de la Constitución a perseguidor de sus autores, además de vilipendiador de las Cortes.

\section{FINAL}

Pero Castro no se contentaba con el triunfo del absolutismo y la represión desarrollada contra los liberales. Para él no había marcha atrás, no existía la posibilidad del arrepentimiento. El número de 24 de marzo de 1815 de la Atalaya registraba su odio sin fin hacia el liberalis-

84 Acta de la "Sesión pública de 2 de setiembre de 1820", Madrid, Imp. especial de las Cortes, 1820 , pp. 2-3.

85 “Cortes. Sesión del dia 2 de setiembre”, en El Universal, núm. 115 (3-9-1820), p. 4. Y “Cortes. Sesión del dia 2", en Miscelánea de Comercio, Política y Literatura, núm. 187 (3-9-1820), p. 4.

86 J. L. Villanueva, Apuntes sobre el arresto de los vocales de las Cortes, egecutado en mayo de 1814 escritos en la cárcel de la Corona, Madrid, Imp, de Diego García Campoy y compañía, 1820. 
mo, con la utilización del sermón de la viña. España era como una viña casi perdida cuando entró a cuidarla el "cautivo, y maravillosamente redimido FERNANDO" ${ }^{77}$. Un jabalí que bajó de la selva la exterminó ("Napoleón que viniendo de Francia la dexaba hecha una horribilísima selva de deistas, materialistas, incrédulos y ateístas") y una fiera singular la "pació" ("Este fue el maldito liberalismo"). Pero si los culpables regresaban, cuando la viña se estaba recuperando, por "todas partes la saquearán y la robarán”. Por ello convenía, se repetía en el sermón, que Fernando no los recibiera en la viña, que los evitara.

Contra esa rígida posición se levantaron algunas voces, como la manifestada en el folleto Clamor de justicia contra los agravios de la Atalaya de 24 de marzo de 1815, escrito, al parecer, por el padre Josef del Salvador ${ }^{88}$. Ante la actitud de Castro respecto a los exiliados liberales escribía que un ministro del Evangelio hace su oficio cuando implora la misericordia para el delincuente arrepentido: "Esta conducta es amable á quien no tiene corazón de fiera". Pero esa no era, desde luego, la actitud de Castro, que no parecía conocer la compasión, que no parecía saber nada de clemencia: ¡Pobre autor de la Atalaya, no estarías hoy tan boyante, en el centro de la Nación, si la Nación se hubiera portado contigo como tú te portas con tus próximos!”. Y el autor del folleto entraba también en las contradicciones del padre Castro, quien predicó sobre la Constitución en Infantes, pueblo de La Mancha, "un sermón tan bonito, que puede servir de modelo á los oradores de este asunto". No podían darse elocuencia y dulzura más elocuentes en elogiar la libertad, la independencia y derechos, lo que contrastaba poderosamente ("Es menester verlo para creerlo", se indicaba en el folleto) con los anatemas que usaba para fulminar después a liberales y afrancesados. Pero el autor de la Atalaya era hombre de peso y como sabio cambió de posición, "volvió la casaca del revés; y aunque se le conocen las puntadas, se incorporó con los buenos españoles". Si él cambió, decía, era posible que otros lo hiciesen y entonces porqué no había de querer para sus hermanos lo que tuvo para él. Eso si, a otros un cambio de postura no les aportó nada, advertía, sin embargo al fraile le significó una "pensioncita de diez mil reales". Y el redactor indicaba en nota a pie de página lo siguiente: "Esta es la pitanza del autor de la Atalaya".

El chaqueteo del padre Castro no fue, ni mucho menos, un caso aislado, hubo más cambios de posicionamientos políticos entre los eclesiásticos. El bibliotecario de las Cortes, Bartolomé José Gallardo, escribió el

87 “Glosa patriótica del Sermón de la viña”, Atalaya de La Mancha en Madrid, núm. 25 (243-1815), pp. 193-198.

88 M. R. P. F. Josef del Salvador, Clamor de justicia contra los agravios de la Atalaya de 24 de marzo de 1815, Valencia, Oficina de Miguel Domingo, 1815. Se trata de una reimpresión. 
Diccionario crítico burlesco, una de las obras satíricas que más influjo tuvo en el anticlericalismo del siglo $\mathrm{XIX}^{89}$, y lo hizo por encargo de grupos liberales en Cádiz para contestar al Diccionario razonado, que apareció en 1811 con el significativo y excluyente subtítulo de "Manual para inteligencia de ciertos escritores que por equivocación han nacido en España" ${ }^{90}$. En este se culpaba de cambio de opinión a los filósofos con la expresión "Cambia colore" o "Especie de magia que usan los filósofos para que los rudos no adviertan sus contradicciones y á favor de la cual dicen boy lo contrario que dixeron ayer"

Gallardo, en la entrada Cambia-colore de su diccionario y tras recordar parte de lo que incluía el Diccionario razonado, afirmaba que los cambiantes y los grandes pecadores contra la patria no eran precisamente los filósofos sino principalmente las "dignidades más visibles de la Iglesia" y casi toda la familia clerical, "desde el chantre melifluo y exquisito, y el beneficiado-simple, al mugriento aquitibi y al portamangas alquilon". Escribía sobre prevaricantes clérigos y frailes de todos los colores los cuales, abusando de su ministerio, "nos quieren persuadir con el Evangelio en la mano que hoy es pecado nefando lo que ayer nos predicaban como obligación sagrada" ${ }^{92}$.

89 Se han publicados muchas ediciones hasta la actualidad. Desde 1811 a 1843 al menos salieron estas: Diccionario critico-burlesco del que se titula "Diccionario razonado. Manual para inteligencia de ciertos escritores que por equivocación han nacido en España", Cádiz, Imprenta del Estado Mayor General, 1811; Diccionario critico burlesco del que se titula "Diccionario razonado. Manual para inteligencia de ciertos escritores que por equivocación han nacido en España", Madrid, Imprenta de Repullés, 1812; Diccionario critico-burlesco del que se titula "Diccionario razonado. Manual para inteligencia de ciertos escritores que por equivocación han nacido en España", Madrid, Librería de Manuel Bueno, 1820; Diccionario crítico-burlesco del que se titula "Diccionario razonado. Manual para inteligencia de ciertos escritores que por equivocación han nacido en España", Madrid, Librería de Manuel Bueno, 1822; Diccionario crítico-burlesco del que se titula "Diccionario razonado. Manual para inteligencia de ciertos escritores que por equivocación han nacido en España”, Marsella, 1823; Diccionario crítico-burlesco del que se titula "Diccionario razonado. Manual para inteligencia de ciertos escritores que por equivocación han nacido en España”, Madrid, Imprenta de Sancha, 1838; Diccionario crítico-burlesco del que se titula "Diccionario razonado. Manual para inteligencia de ciertos escritores que por equivocación han nacido en España", Madrid, 1843.

90 He localizado tres ediciones pero seguramente salieron más: S. C. T., Diccionario razonado. Manual para inteligencia de ciertos escritores que por equivocación han nacido en España. Obra útil y necesaria en nuestros días, Cádiz, Imp. de la Junta Superior de Gobierno, 1811; S. C. T., Diccionario razonado. Manual para inteligencia de ciertos escritores que por equivocación han nacido en España, Santiago, Juan Francisco Moreno, 1811; y Diccionario razonado. Manual para inteligencia de ciertos escritores que por equivocación han nacido en España. Aumentado con más de cincuenta voces y una receta eficacísima para matar insectos filosóficos, Cádiz. Imp. de la Junta Superior, $1811,2^{\mathrm{a}}$ ed.

91 Diccionario razonado..., pp. 6 y 7. Paro recordar el tono de este diccionario se puede recordar, por ejemplo, una definición de humanidad en la página 11: "Amor á los malhechores, piedad con las prostitutas, inflexibilidad con los clérigos, frailes, etc. y olvido total de Dios".

92 Diccionario crítico-burlesco..., pp. 22-24. 
Cambios de posición de filósofos, variaciones de clérigos... Y andando el tiempo esa actitud llegó a identificarse fundamentalmente con los políticos. En el diccionario de Rico y Amat de 1855, por ejemplo, eran los políticos, ya con la expresión camaleón ${ }^{93}$, los chaqueteros: "Político que muda de opiniones con frecuencia y facilidad, como dicen que muda de colores ese fabuloso animal”. El camaleón político, añadía, vistió ayer de blanco, hoy de negro y mañana de encarnado; en el año 24 lució el uniforme de realista y hoy el de miliciano nacional; en el 24 cantó la pitita $^{94}$ a los liberales y en el 34 el trágala ${ }^{95}$ a los realistas. Y concluía la entrada recordando que el camaleón sólo se alimenta del aire, según los que le habían visto, pero el político del "turrón y otras golosinas".

En fin, bien hizo en morirse el padre Castro el año veinte cuando escuchó el grito de la Constitución, escribía Carlos Le Brun en su obra sobre Fernando VII ${ }^{96}$, pues en caso contrario hubiera tenido que presentar el original de la constitución que imprimió y repartió por las esquinas, con unos principios que aun para soñarlos, como él, "era necesario tener una cabeza cafre, y un corazón de hyena con un descaro algo más que frailuno".

93 J. Rico y Amat, Diccionario de los politicos, verdadero sentido de las voces y frases más usuales entre los mismos, escrito para divertimiento de los que ya lo han sido y enseñanza de los que aun quieren serlo, Madrid, Imp. de F. Andrés y compañía, 1855, pp. 87-88.

94 "Pitita, bonita, // con el pío, pío, pon; // ¡Viva Fernando // y la inquisición!”. L. Díaz Viana, "Las canciones populares en nuestra historia (Absolutistas y liberales)", en Revista de Folklore, núm. 4 (1981), pp. 28-32.

95 Se fueron sucediendo letras diversas. En la época fue frecuente: "Trágala, trágala // vil servilón // tú que no quieres // Constitución". Los absolutistas contestaron con: "Trágala, trágala // tú liberal // tú que no quieres //corona real".

96 C. Le Brun, “Anécdota cuadragésima tercera”, en Vida de Fernando Séptimo, Rey de España, ó Colección de anécdotas de su nacimiento y de su carrera privada y política, publicadas en castellano por Don Carlos Le Brun, ciudadano de los Estados Unidos é intérprete del Gobierno de la República de Pensilvania, Filadelfia, 1826, pp. 76-77. 


\section{ORACTON}

QUE EN LA MISA SOLEMNE DE LA jURA

DE LA CONSTITUCION POLITICA

DE LA NLCION ESPAÑOLA

Dixo

A LA JUNTA SUPERIOR

$Y$ PUEBLD DE INFANTES

EL RED ACTOR DE LA GAEETA DE LA MANCHA.

此视

ELCHE DZ IA STENRA:

En la Imprenta de dicha Junta Superior. Liso de 1812.

1812

Num. 1, .

GAZETA DË LA PROVINCIA

DE LA XAYCBA.

PEL SÁBADO. z DE ENERO DE i8ız.

\section{GRAN-BRETARA}

Liendres 17 de noviembire.

Ia péritida de oficiales franceses en la batalts de Borodico debió de ser inmenan Las curtas de Paris tecibitas al misto tiempo que los periódicos, aseguran que casi todas las familiai de la antigua nobleza de Francia cstabas de luto por las infaus tas,noticias de los oficiales muertos en Rusia.

- Ungrarta da Riga de 27 del antcrior dice lo siguieate. " Wirtgensteín entro en Polosk el 8 de.ostubre. El general St. Cye geretira hacis Wilna, habiendo perdido en la ultima ba-

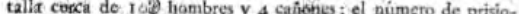
neros arciende remuido don Wittgentein, $y$ segun ole has as, Steinheil se ha retuido con Wilgenstein, y scgun me ha asegurado un edecan de éste los dos cuerpos combinados aciénder à 502 bombres. El mismo general Wirtgenstein asegura que nos libertará pronto de Macionald. Los franceses han evacuado a Witepok, EI general Lewis se mantiene en las mismas posiciones : sus piquetes se extieudea hasta. Ecko en el camino de Bauke, y liasta Oley en la ruta que conduce á Mirtav. "

$$
\text { Badajoz } 20 \text { de dicimbre. }
$$

Los periodicos de Lisboa extractan los des Ǵtrimos paquetes ingleses, cuyas intercsantes noticias no hemos querifo retar- 
PROSPECTO AL NUEVO PERIÓDICO

$A T A L A Y A \mathbb{D E}$ IA $M A N C H A$

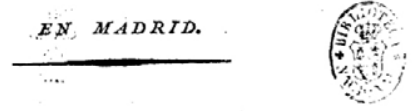

${ }_{\mathrm{W}}$, señores publicistas liberales! $\mathrm{Ya}_{a}$ tienen $\mathrm{vds}$. a su disposicion el ; campo de la Mancha. Victoria por las armas de los cafes: vencieron los Apolizantes; y el P. Gacetero fué atario al carro de su triunfo: apuntaron, dispararon, trun........ á tierra con el fraile ; una boca ménos en el coro de los mamantes.

boca ménos en el coro de los mamantes.
Pues, señores; no se lo rian vds. todo : ya que han logrado la satisfaccion de dejarme in puris, déjenme siquiera el miserable consuelo de quitarles algo mas de la mitad de la gloria que quieren apropiarse en el vençimiento. Porque en suma ique es lo que vds. han hecho? Honrarue con eacs chillidos de grilleru Que vie no? Honrarue con esos chillidos de grillera. Que vie no.el Conciso..... que turna el Mercantil..... que va el Redactor..... que asoma la Abeja..... allá va el Tribuno..... iY que dicen estos danzantes? Que el fraile....... que el P. Gacetero.... Nada : que los aprieta las clavijas; que los da á conocer; que descubre la hilaza; que entorpece el curso de la cofradía de Orates. iEsas tiene el frailecico? Salgan las guerrillas con b́rdenes de no dar cuartel: ver si se rinde á las primeras intimaciones: $i$ se resiste? Apliquen la mecha, y vuele por esos aires. ; Bravo! ; Bravísimo!

Mas yo, para dejarme volar, he necesitado de toda la fibra de un héroe. iQue? $i$ No hai sino hacer dos higas al hambre, que con una cara de herege viene revoloteando sobre mi cabeza? $\mathrm{Si}$ a las primeras insinuaciones que vinieron de ahí hubiera yo aflojado..... Si á las echadizas que venian á mis amigos me hubiera puesto entre los dos coros.... si hubiera hecho cara á las promesas..... si hubiera temido las amenazas..... ¿ $\mathrm{Me}$ esplico? Pero el Padrecico tiene hijares; lo leía , y......... (C) Biblioteca Nacional de España

4-7-1813

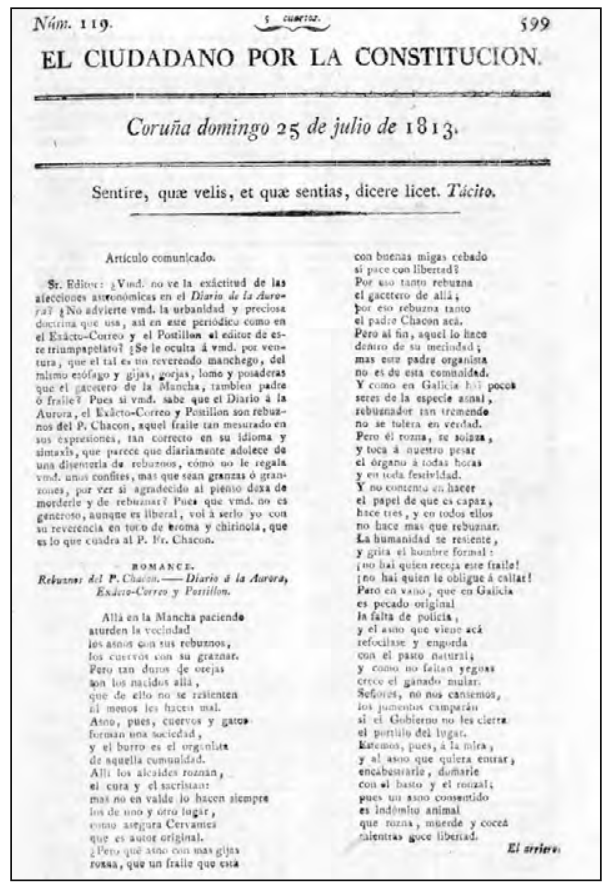

$25-7-1813$ 


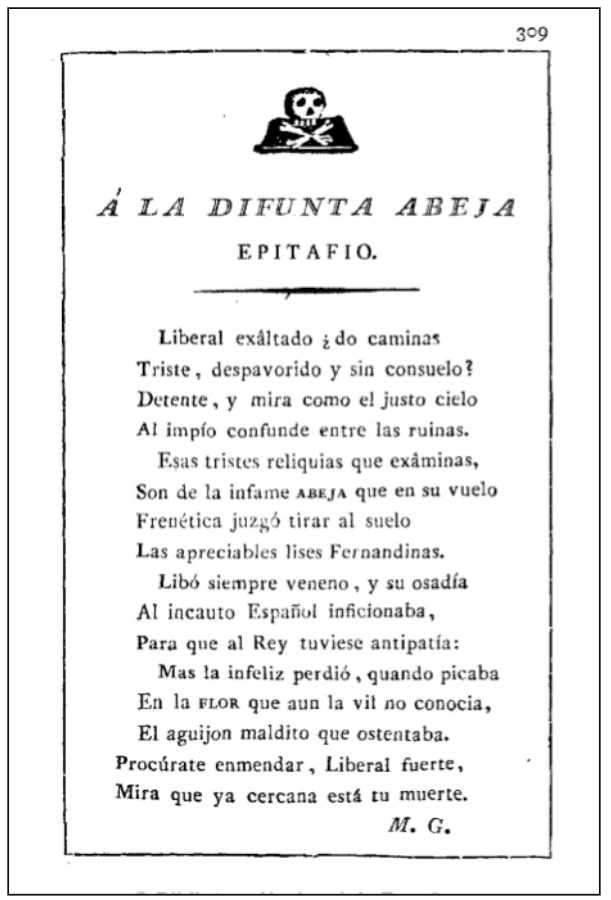

Atalaya de La Mancha en Madrid, 9-5-1814

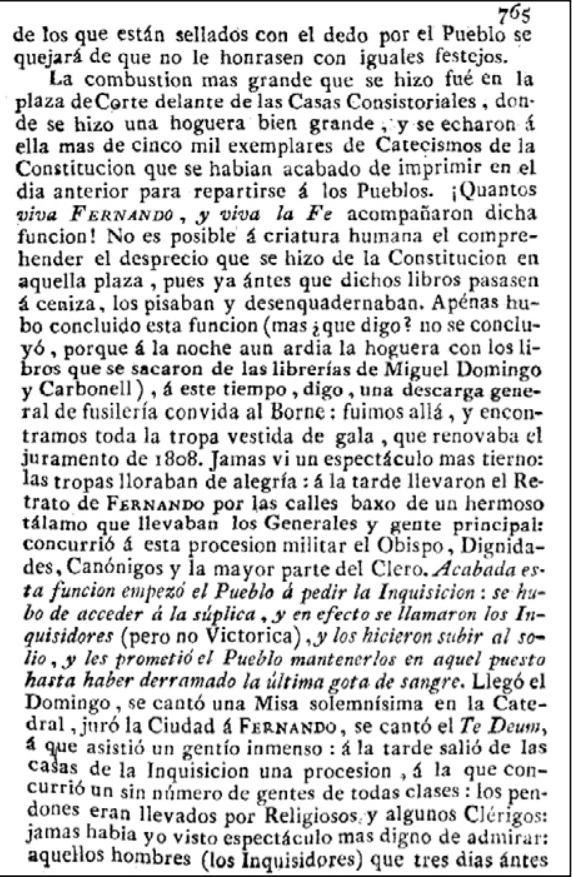

Quema de libros en Palma de Mallorca. Atalaya de La Mancha en Madrid, 3-7-1814 


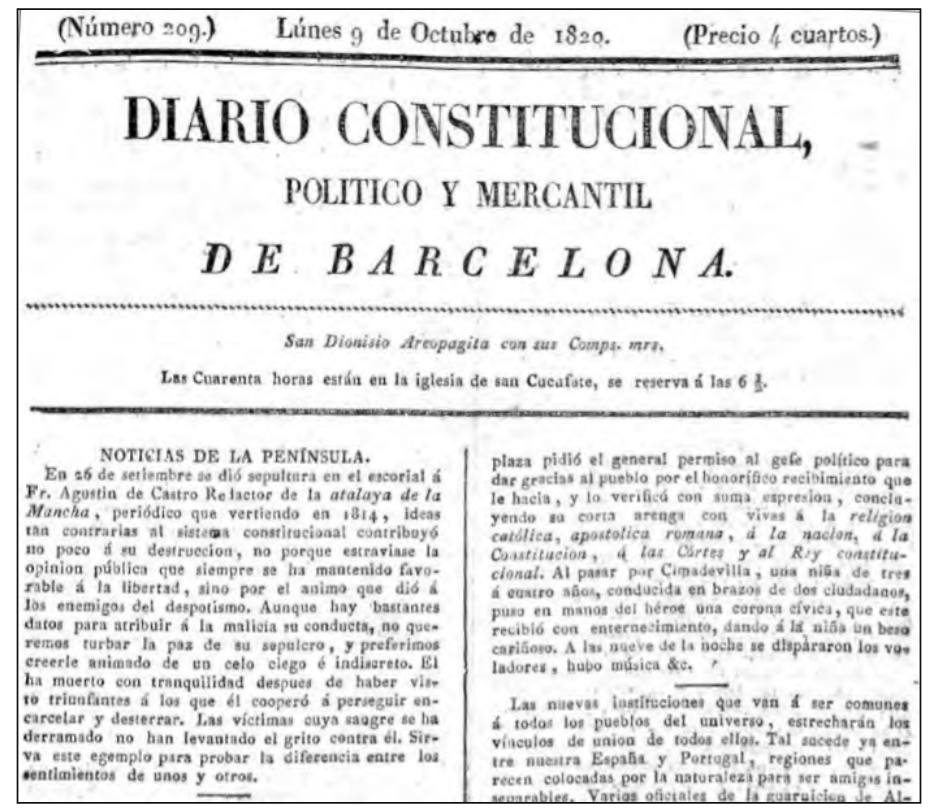

Noticia de la muerte de Agustín Castro en 1820

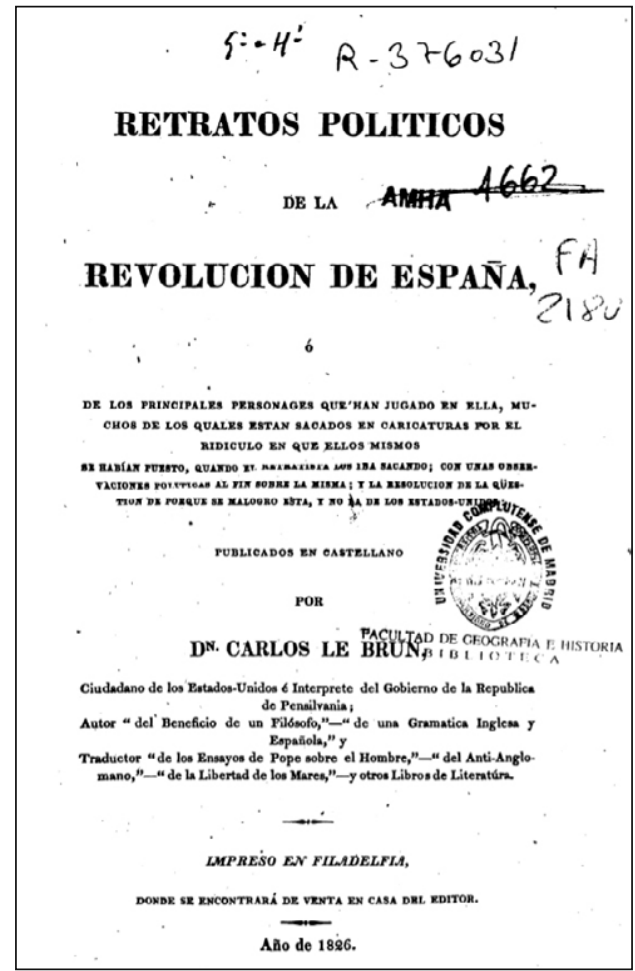

1826 
SI,

EN EL UNTVERSO,

HAY

UN HOMBRE QUE NO

ABORREZCA

AL

EXECRABLE FERNANDO DE BORBON,

LEA ESTA OBRA,

é

NSTRUIDO CON SU LECTURA,

LE

ABORRECERÁ

1826. Vida de Fernando VII (Carlos Le Brun)

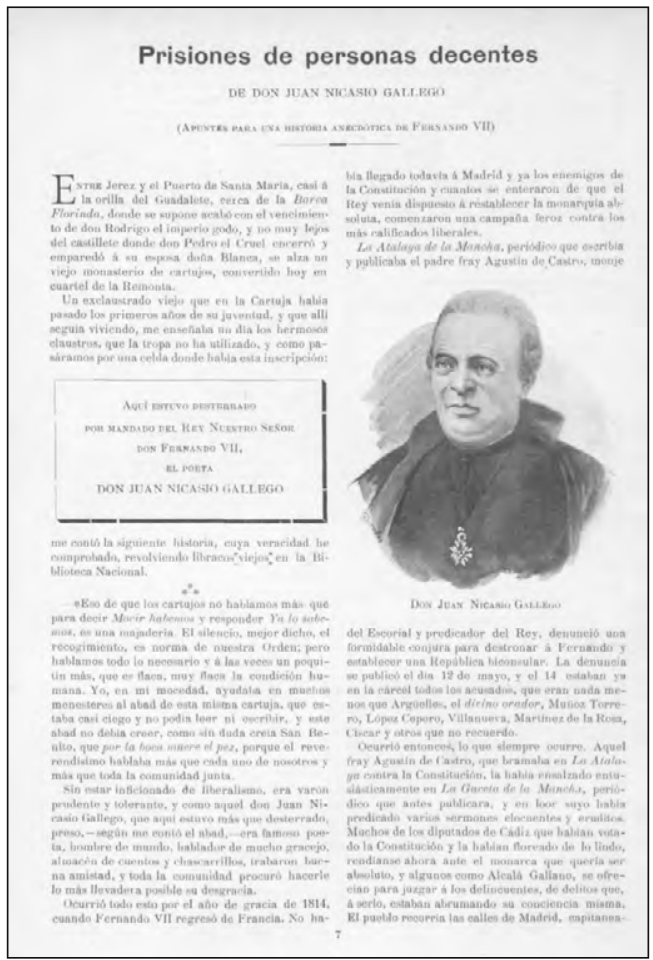

Pluma y lápiz (Barcelona, 1903) 


\section{CONQLENSIS ILLSTRES AGUSTIN CASTRO}

Fraile del monasterio d I lis. corial y periodista." Era natura de Tarancón. De temperamento exaltado $y$ de ideas altamente radicales en sentido absolutista, dirigió en 1813 en la Corte el periódico titulado -Atalaya de la Mancha en Madrid•, apasionado defensor de Fernando VII como monarca absoluto $\mathbf{y}$ despiadado enemigo de cuanto fuera liheral o simpatizara con estas ideas. Fué objeto de numerosas persecuciones y más de una vez vió su vida en peligro. Ossorio y Bernard en su -Catálogo de periodistas espa. nooles. dice: - La Atalaya ha sido una de las publicaciones que más caracterizaron la época de apasionamiento $y$ odios en que se public6.

También escribió en $\cdot \mathrm{La} \mathrm{Ga}$ ceta de la Mancha. y figuró en todas las juntas realistas que por entonces se formaron. Huido cuando la segunda época constitucional, no volvió a saberse de este esaltado personaje, figuran do, sin duda, en las filas de los
| eagraviados precursores de Ins que anิos dexpués se denominaron con el título de -carlistas.

Ilablando Ilartzembusch de la - Atalaya de la Mancha en Madrid- dice: - Fué un periblico político, vivo defensor del Rey l'ernando VII, que sostuvo fuertes polémicas con varios periódicos liherales. Por el eslilo fuerte yue usó este religioso en uno de sus números, se le formó causa y se le redujo a prisión, antes, como es de suponer, de la venida del Rey a España. Ayudaron al $\mathrm{Pa}$ dre Castro, el capellín Sinueva y el mercedario Fray Miguel Martínez*--Alvarez M. del Peral.

EL DIA DE Se venCUENCA de en el CUENCA salón de Limpiabotas de la calle de Mariano Catalina, 34; Bar Ideal y en el Quiosco de bebidas y refrescos de la Estación desde las 6 de la mañana.

El Día de Cuenca, 6-5-1928 
